\title{
Revisiting tolerance to ocean acidification: Insights from a new framework combining physiological and molecular tipping points of Pacific oyster
}

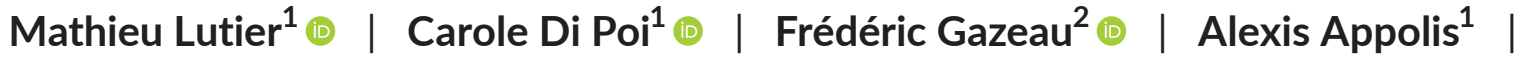 \\ Jérémy Le Luyer ${ }^{3}{ }^{\oplus}$ | Fabrice Pernet ${ }^{1} \odot$
}

${ }^{1}$ Univ Brest, Ifremer, CNRS, IRD, LEMAR,

Plouzané, France

${ }^{2}$ Laboratoire d'Océanographie de Villefranche, LOV Sorbonne Université, CNRS, Villefranche-sur-Mer, France

${ }^{3}$ EIO UPF/IRD/ILM/Ifremer, Labex CORAIL, Unité RMPF, Centre

Océanologique du Pacifique, Vairao,

French Polynesia

Correspondence

Fabrice Pernet, Univ Brest, Ifremer, CNRS, IRD, LEMAR, F-29280 Plouzané, France.

Email: fpernet@ifremer.fr

Funding information

Foundation for Research on Biodiversity;

French Ministère de la transition

écologique

\begin{abstract}
Studies on the impact of ocean acidification on marine organisms involve exposing organisms to future acidification scenarios, which has limited relevance for coastal calcifiers living in a mosaic of habitats. Identification of tipping points beyond which detrimental effects are observed is a widely generalizable proxy of acidification susceptibility at the population level. This approach is limited to a handful of studies that focus on only a few macro-physiological traits, thus overlooking the whole organism response. Here we develop a framework to analyze the broad macro-physiological and molecular responses over a wide $\mathrm{pH}$ range in juvenile oyster. We identify low tipping points for physiological traits at $\mathrm{pH}$ 7.3-6.9 that coincide with a major reshuffling in membrane lipids and transcriptome. In contrast, a drop in $\mathrm{pH}$ affects shell parameters above tipping points, likely impacting animal fitness. These findings were made possible by the development of an innovative methodology to synthesize and identify the main patterns of variations in large -omic data sets, fitting them to $\mathrm{pH}$ and identifying molecular tipping points. We propose the broad application of our framework to the assessment of effects of global change on other organisms.
\end{abstract}

\section{KEYWORDS}

acidification, lipidomic, mollusk, reaction norm, threshold, transcriptomic

\section{1 | INTRODUCTION}

The exponential increase in the atmospheric emission of carbon dioxide $\left(\mathrm{CO}_{2}\right)$ from anthropogenic activities is mitigated by ocean absorption that leads to decreasing ocean $\mathrm{pH}$ and changes in carbonate chemistry, a phenomenon known as ocean acidification (OA; Caldeira \& Wickett, 2003; Orr et al., 2005). This represents a tremendous challenge for marine organisms, especially for calcifiers that produce calcium carbonate $\left(\mathrm{CaCO}_{3}\right)$-based exoskeletons. OA not only induces internal acidosis that impacts metabolism, behavior, growth, and reproduction but also decreases carbonate ion $\left(\mathrm{CO}_{3}{ }^{2-}\right)$ concentration in the ocean, the elemental constituent of calcifier exoskeletons (Gazeau et al., 2013; IPCC, 2019; Kroeker et al., 2013; Tresguerres \& Hamilton, 2017 for reviews).
OA has been the most-studied topic in marine science in recent times (Browman, 2017). As such, many OA experiments have been conducted, usually exposing organisms to experimental conditions based on scenarios modelled for open ocean waters, typically simulating present and near-future surface ocean $\mathrm{pH}$ levels. However, many calcifying species thrive in coastal areas where $\mathrm{pH}$ levels vary far more than in the open ocean on both daily and seasonal scales (Vargas et al., 2017; Waldbusser \& Salisbury, 2014). As a result, several authors have applied $\mathrm{pH}$ offsets or conditions that are more locally relevant (Dineshram et al., 2015; Gazeau et al., 2014; Ko et al., 2014), but the results cannot be extrapolated to populations or species that are distributed in a mosaic of habitats. We need to implement experimental approaches whose results can be applied in a wide range of environments at the scale of species (Vargas et al., 2017). 
Reaction norm, that is, the response of an organism to changing environmental parameters, allows the identification of tipping points that beyond small variations will have major impacts. According to the last IPCC reports, identification of tipping points is a key knowledge gap in environmental change research (IPCC, 2019, 2021). Tipping point is valid for a whole population regardless of habitat. In addition, this is a single, easily communicable value that reflects susceptibility to OA (Bednaršek et al., 2019, 2021). To date, only four studies have experimentally established reaction norms for marine calcifiers in relation to $\mathrm{pH}$. These studies focused on the assessment of tipping points for a few selected traits measured at the organism level (i.e. growth, survival) and provide a limited view of the whole organism response, ignoring molecular responses (Comeau et al., 2013; Dorey et al., 2013; Lee et al., 2019; Ventura et al., 2016). We, therefore, identify the need to integrate macro-physiology and omics together with reaction norms, for understanding the mechanisms responsible for individual organism success under a changing environment. This, however, requires developing an innovative methodology to synthesize and identify the main patterns of variations in large -omics data sets (Strader et al., 2020) and fit them to reaction norms.

Lipidomic and transcriptomic approaches provide complementary and holistic views of organismal responses to environmental changes at the molecular and biochemical levels. Membrane lipids modulate exchanges between the intracellular milieu, which is highly regulated, and the extracellular milieu, which reflects environmental changes, and therefore play a key role in metabolic regulation and ion exchanges (Hazel \& Williams, 1990; Hochachka \& Somero, 2002; Hulbert \& Else, 1999). However, the role of membrane lipids in the regulation of acid-base equilibrium and biomineralization under $\mathrm{OA}$ has never been investigated. Here we expect that membrane lipids play a key role in the maintenance of electrochemical gradient across membranes, a parameter that is essential for organism's persistence under OA (Cyronak et al., 2016).

The transcriptomic response is one of the first level of metabolic regulation that determine shifts in acid-base ion regulation, metabolic processes, calcification, and stress response mechanisms (Matz, 2018; Strader et al., 2020). Although an increasing number of studies investigate the transcriptomic responses of marine calcifiers under OA, they generally focus on a few targeted genes that play a central role in physiological processes and they assume that gene functions are conserved among taxa (Strader et al., 2020). This creates a vicious cycle limiting the opportunities to uncover new mechanisms and cellular pathways involved in organism responses to OA. New methodologies are, therefore, required to provide new insight on organism's response to OA at the transcriptional level (Rajan et al., 2021; Yarra et al., 2021).

Here we determine the reaction norm of juvenile Pacific oyster Crassostrea gigas, one of the most cultivated invertebrate species in the world (FAO, 2020), over a wide range of $\mathrm{pHs}$ for macrophysiological traits, membrane lipids, and gene expression. Although the impacts of OA on this model species have been intensively studied using scenario approaches, there is currently no consensus on its robustness to low pH (Ducker \& Falkenberg, 2020). The establishment of reaction norm with biochemical and molecular data is a novel approach that provides new insights on the sensitivity of marine calcifiers to $O A$.

\section{2 | MATERIALS AND METHODS}

\subsection{Animals and maintenance}

The oysters were produced at the Ifremer hatchery facilities in Argenton (Brittany, France) in late August 2018 according to Petton et al. (2015). The broodstock consisted of 139 females and 40 males originating from six different cohorts collected in the natural environment between 2011 and 2016, off Fouras (Ile d'Aix). At 40 days old, the juveniles were moved to the Ifremer growing facilities in Bouin (Vendée). On January 10, 2019, oysters were returned to Argenton and kept for 8 days in a $500 \mathrm{~L}$ flowthrough tank. Seawater temperature was gradually increased from 7 to $22^{\circ} \mathrm{C}$, the optimal temperature for C. gigas (Bayne, 2017), at a rate of ca. $2^{\circ} \mathrm{C} \mathrm{day}^{-1}$. During the experiment, oysters were continuously supplied with natural seawater originating from a pool $\left(\sim 9000 \mathrm{~m}^{3}\right)$ which is renewed with each spring tide, filtered at $5 \mu \mathrm{m}$ and UV-treated. The oysters were fed continuously on a mixed diet of Isochrysis affinis galbana (CCAP 927/14) and Chaetoceros gracilis (UTEX LB2658) (1:1 in dry weight). Food concentration was maintained at $1500 \mu \mathrm{m}^{3} \mathrm{ml}^{-1}$ of phytoplankton cells at the outlet of the tank-ad libitum (Rico-Villa et al., 2009)-and controlled twice daily using an electronic particle counter (Multisizer 3 , Beckman Coulter) equipped with a 100- $\mu \mathrm{m}$ aperture tube. On the eve of the experiment on January 14, 2019, at which point they were 5 -month-old, oysters were divided into 15 batches containing $292 \pm 20$ individuals $(95.2 \pm 0.2 \mathrm{~g})$.

\section{2 | Experimental design}

Each batch of oysters was exposed to one constant nominal $\mathrm{pH}$ condition ranging from $\mathrm{pH} 7.8$ to 6.4 with a step of 0.1 between two levels. The upper $\mathrm{pH}$ condition $(\mathrm{pH} \sim 7.8$ ) was obtained by running seawater with oysters without $\mathrm{pH}$ regulation. The lowest $\mathrm{pH}$ values encountered by oysters today are presumably between $\mathrm{pH} 7.4$ and 7.0 (Frankignoulle et al., 1996; Melzner et al., 2013; Proum et al., 2017; Wallace et al., 2014). Geochemical models using the record of atmospheric $\mathrm{CO}_{2}$ levels over the last $300 \mathrm{Myr}$ suggest that the ocean pH was at most 0.6 units lower than today (Caldeira, 2003). Continued release of $\mathrm{CO}_{2}$ from fossil fuels into the atmosphere (worst case scenario) could result in a reduction in $\mathrm{pH}$ of 0.7 units at the ocean surface (Caldeira, 2003). Therefore, the lowest $\mathrm{pH}$ values used in our study are probably unrealistic but expand the reaction norms and increase the statistical power of the tipping point.

The experimental system consisted of 18 experimental units that were randomly assigned to one $\mathrm{pH}$ condition $(n=15$, no $\mathrm{pH}$ replication) or to control blanks without animals ( $n=3$; Figure S1). 
Each experimental unit consisted of a header tank in which seawater was acidified (except for the ambient $\mathrm{pH}$ and blanks) and then delivered by a pump to a holding tank containing the oysters. These tanks were $45 \mathrm{~L}$, and their entire volume was renewed every $82 \mathrm{~min}$. $\mathrm{pH}$ was regulated by means of pure- $\mathrm{CO}_{2}$ bubbling, controlled by a $\mathrm{pH}$-regulator (ProFlora ${ }^{\circledR} \mathrm{u} 403 \mathrm{JBL}$ ). The $\mathrm{pH}$-regulator was connected to $\mathrm{pH}$-probes installed in each header tank $(\mathrm{pH}$-sensor+Cal, $J B L)$, checked at the start of the experiment using Certipur ${ }^{\circledR}$ Merck NBS buffers ( $\mathrm{pH}=4.00, \mathrm{pH}=7.00)$. $\mathrm{pH}$ electrodes from the $\mathrm{pH}$ regulator were inter-calibrated twice daily against a $\mathrm{pH}$ probe (Sentix ${ }^{\circledR}$ 940-3 WT) connected to a Multiline ${ }^{\circledR}$ Multi 3630 IDSWTW. The $\mathrm{pH}$-probe was checked once a week using Certipur ${ }^{\circledR}$ Merck NBS buffers ( $\mathrm{pH}=4.00,7.00$, and 9.00) and calibrated twice a week on the total scale with a certified $\mathrm{Tris} / \mathrm{HCl}$ buffer (salinity 35; provided by A. Dickson, Scripps University). Throughout the text, $\mathrm{pH}$ levels are therefore expressed on the total scale $\left(\mathrm{pH}_{\mathrm{T}}\right)$. In each experimental tank, air bubbling and a small homogenization pump ( $3 \mathrm{~W}$ ) ensured an efficient mixing of seawater surrounding the oysters. Photoperiod was $10 \mathrm{~h}$ light: $14 \mathrm{~h}$ dark. During the entire experimental period, oysters were fed as described above.

On January 18, 2019, each batch of oysters was randomly assigned to one tank. Oysters were first held at ambient $\mathrm{pH}$ for $3 \mathrm{~d}$. Then, $\mathrm{pH}$ was progressively decreased in each $\mathrm{pH}$-regulated tank at a rate of 0.2-unit day ${ }^{-1}$. The decrease in $\mathrm{pH}$ lasted for 7 days for the lowest condition. Experimental pH conditions were all reached on January 27, 2019. The $\mathrm{pH}$ exposure lasted 23 days, the time required for critical shell alteration (bleaching, perforation, and dissolution) under the lowest $\mathrm{pH}$ conditions. No mortality was recorded during the experiment.

\section{3 | Seawater carbonate chemistry}

In each oyster tank, temperature, salinity, dissolved oxygen $\left(\mathrm{O}_{2}\right)$ saturation levels, and $\mathrm{pH}$ were measured twice a day using a Multiline ${ }^{\circledR}$ Multi 3630 IDS-WTW (pH probe Sentix ${ }^{\circledR}$ 940-3 WTW, $\mathrm{O}_{2}$ probe FDO ${ }^{\circledR} 925$ WTW, salinity probe TetraCon ${ }^{\circledR} 925$ WTW). Seawater samples were collected weekly, filtered through $0.7 \mu \mathrm{m}(\mathrm{GF} / \mathrm{F}$, Whatman ${ }^{\circledR}$ ) and poisoned with $0.05 \%$ mercury (II) chloride. Total alkalinity (TA) was then measured in triplicate $50 \mathrm{ml}$ subsamples by potentiometric titration at $22^{\circ} \mathrm{C}$, using a Titrando 888 (Metrohm ${ }^{\circledR}$ ) titrator coupled to a glass electrode (ecotrode plus, Metrohm ${ }^{\circledR}$ ) and a thermometer (pt1000, Metrohm $\left.{ }^{\circledR}\right)$. TA was calculated following the protocol described in Dickson et al. (2007). At the time of sampling, $\mathrm{pH}$, salinity, and temperature were measured and then used together with TA value to determine carbonate chemistry parameters using the package seacarb $v$ 3.2.16. of the R software.

\section{4 | Biometry}

The total fresh weight (shell + tissue) of each batch of oysters was measured twice weekly and interpolated between measurements to estimate daily weight. In addition, shell length and total fresh weight were measured individually on 30 oysters from each condition at the onset ( 1 day) and at the end of the experiment (23 day). The measurements relate to different individuals taken over time. These oysters were then dissected and pooled to determine the total weight of shell and tissue, separately. The tissues were then Iyophilized and weighted to obtain dry weight. Growth rate was calculated as:

$$
G=\left(\overline{X_{23}}-\overline{X_{1}}\right) \div 23
$$

where $G$ is growth rate as expressed as increase in shell length or total body weight per day $\left(\mathrm{mm} \mathrm{day}^{-1}, \mathrm{mg} \mathrm{TW} \mathrm{day}^{-1}\right), \overline{X_{1}}$ and $\overline{X_{23}}$ are the average parameter values for shell length and total weight measured at the onset ( 1 day) and the end of the experiment (23 days).

Shell thickness was measured on the left valve of five individuals collected per $\mathrm{pH}$ condition at the end of the experiment. The left valve was more susceptible to acidification than the right valve. We observed holes in the shell under low $\mathrm{pH}$ condition $(\mathrm{pH}<6.6)$ that always occurred on the left valves, close to the umbo. Shells were dried for $24 \mathrm{~h}$ at $45^{\circ} \mathrm{C}$, embedded in polyester resin and cross-sectioned from umbo to opposite shell margin along the longitudinal growth axis using a precision saw (Secotom-10 Struers). Sections were glued on a microscope slide and polished with silicon carbide abrasive disks ( 1200 and 2500 grains $\mathrm{cm}^{-2}$ ). Images of the section were captured under a Lumar V12 stereoscope (Zeiss) at 30x magnification, and the entire section was reconstructed using an image acquisition software (AxioVision SE 64 - v4.9.1, Zeiss). The minimal shell thickness was measured within the first third of the shell starting from umbo using ImageJ software (Schneider et al., 2012).

\section{5 | Physiological rates}

Seawater was sampled twice a day at the inlet and outlet of each oyster tank, and phytoplankton cell concentrations were measured using an electronic particle counter (see the previous section). No pseudofeces production was detected throughout the experiment. Ingestion rate was determined as:

$$
I=\frac{\Delta_{\text {phyto }} \times \text { flow rate }}{W},
$$

where $I$ is the ingestion rate expressed as $\mathrm{cm}^{3} \min ^{-1} \mathrm{~g}^{-1}, \Delta_{\text {phyto }}$ is difference in phytoplankton concentrations between the inlet and the outlet of the oyster tanks $\left(\mathrm{cm}^{3} \mathrm{~min}^{-1}\right)$, flow rate is the water flow at the inlet of the oyster tanks $\left(\mathrm{ml} \mathrm{min}^{-1}\right)$, and $W$ is the total fresh weight of oyster batch $(\mathrm{g})$. The three control blanks were used to check that there was no sedimentation of algae (no differences in cell concentrations between the inlet and the outlet, data not shown). 
Net calcification and respiration rates were measured after 22 days of exposure. Food supply was stopped $17 \mathrm{~h}$ before the assay and tanks were emptied, cleaned and refilled. Again, $1 \mathrm{~h}$ before the assay, the tanks were emptied, cleaned, and refilled. At the onset of the incubation, water flow and air bubbling were stopped. Gentle mixing of the seawater was maintained by homogenization pump, but air bubbling was stopped. Incubations lasted for $90 \mathrm{~min}$. This duration allowed to keep the $\mathrm{pH}$ close to the setpoint $(<0.1 \mathrm{pH}$ unit variation) despite oyster respiration. At the onset and at the end of the incubation period, temperature, salinity, $\mathrm{pH}$, and $\mathrm{O}_{2}$ concentration $\left(\mathrm{mg} \mathrm{L}^{-1}\right.$ ) were measured, and seawater samples were filtered and poisoned for TA analyses (see above) or were immediately frozen at $-20^{\circ} \mathrm{C}$ for ammonium $\left(\mathrm{NH}_{4}{ }^{+}\right.$) measurements (Aminot \& Kérouel, 2007; see Table S1). Empty tanks were used as controls to check that there was no change in any of the parameters due to evaporation or other potential biological processes in the water itself. Net calcification rate was determined following a modified procedure from Gazeau et al. (2015) using the alkalinity anomaly technique (Smith \& Key, 1975):

$$
\mathrm{NC}=\frac{\left(\Delta_{\mathrm{TA}} \times \rho-\Delta_{\mathrm{NH}_{4}^{+}}\right) \times \mathrm{V}}{2 \times t \times \mathrm{W} \times \frac{\mathrm{DW}}{\mathrm{TW}}},
$$

where NC is the net calcification rate expressed as $\mu \mathrm{mol}$ $\mathrm{CaCO}_{3} \mathrm{~h}^{-1} \mathrm{~g}^{-1}, \Delta_{\mathrm{TA}}$ and $\Delta_{\mathrm{NH} 4+}$ are differences in TA $\left(\mu \mathrm{mol} \mathrm{Kg}^{-1}\right.$ ) and $\mathrm{NH}_{4}{ }^{+}\left(\mu \mathrm{mol} \mathrm{L}{ }^{-1}\right)$ between the onset and the end of the incubation period, $\rho$ is seawater density $\left(\mathrm{kg} \mathrm{L}^{-1}\right)$ calculated based on temperature and salinity during the incubation, $V$ is the volume of the tanks $(L)$, $t$ is the duration of the incubations (h), $\frac{D W}{T W}$ is the ratio of dry weight and total weight determined after lyophilization of a pool of tissues from 30 oysters (see above).

Respiration rate was determined following:

$$
R=\frac{\left(\Delta_{\mathrm{O}_{2}}-\Delta_{\mathrm{O}_{2} \text { Control }} \times \rho\right) \times V}{t \times W \times \frac{\mathrm{DW}}{\mathrm{TW}}},
$$

where $R$ is the respiration rate expressed as $\mathrm{mg} \mathrm{O}_{2} \mathrm{~h}^{-1} \mathrm{~g}^{-1}, \Delta_{\mathrm{O}_{2}}$ and $\Delta_{\mathrm{O}_{2 \text { control }}}$ are differences in $\mathrm{O}_{2}$ concentration $\left(\mathrm{mg} \mathrm{L}^{-1}\right)$ between the onset and the end of the incubation period in the oyster tank and in the three control tanks (average), respectively. Negative values mean that oxygen consumption was negligible and similar to control blanks.

\section{6 | Biochemistry}

Soft-tissues of five individuals from each $\mathrm{pH}$ condition were collected at 23 days, flash-frozen in liquid nitrogen, pooled, grounded with a ball mill, and stored at $-80^{\circ} \mathrm{C}$ pending analyses. Oyster powder was diluted with chloroform/methanol $(2: 1, v / v)$ for the determination of neutral lipids (triacylglycerol: TAG, and sterols: ST) using high-performance thin-layer chromatography. TAG-ST ratio was used as a proxy of the relative contribution of lipid reserve to structure (membrane). Polar lipids were purified on silica gel micro column, transesterified using methanolic $\mathrm{H}_{2} \mathrm{SO}_{4}$ at $100^{\circ} \mathrm{C}$, and the resulting fatty acid methyl esters were analyzed using a gaschromatography flame ionization detection system equipped with a DB-Wax capillary column. Peaks were analyzed by comparison with external standards. Each fatty acid was expressed as the peak area percentage of total polar fatty acids. Carbohydrate content $\left(\mu \mathrm{g} \mathrm{mg}^{-1}\right.$ ) was determined according to the colorimetric method described in DuBois et al. (1956).

\section{7 | Transcriptomics}

Soft-tissues of five individuals from each tank were collected at 23 days, flash-frozen in liquid nitrogen, and individually grounded ( $n=75$ ). Total RNA was then extracted with Extract-All (Eurobio) at a ratio of $5 \mathrm{ml}$ per $100 \mathrm{mg}$ of tissue. RNA quantity/integrity and purity were verified with a NanoDrop 2000 spectrophotometer (Thermoscientific ${ }^{\circledR}$ ) and a Bioanalyzer 2100 (Agilent Technologies $\left.{ }^{\circledR}\right)$, respectively. Samples were then DNase-treated using a DNase Max ${ }^{\mathrm{TM}}$ Kit (MO BIO Laboratories, Inc.) and analyzed at the Genotoul sequencing platform (INRAE US 1426 GeT-PlaGe, Centre INRAE de Toulouse Occitanie, Castanet-Tolosan). TruSeq RNA libraries were multiplexed and sequenced on a single lane of NovaSeq6000 Illumina S4 150-bp paired-end.

Raw reads were first filtered using Trimmomatic v.0.36 for a minimum length ( $60 \mathrm{bp}$ ), a minimum quality (trailing $=20$, leading $=20$ ), and the presence of potential contaminants and remaining adaptors (https://ftp.ncbi.nlm.nih.gov/pub/UniVec; 08/17/20). The quality of the reads was monitored before and after this trimming process with FastQC v.0.11.5 (https://www.bioinforma tics.babraham.ac.uk/projects/fastqc/). The $C$. gigas reference genome (Peñaloza et al., 2021) was downloaded from NCBI (GCF_902806645.1) and indexed with Gmap v2020.06.01. Filtered reads were mapped against the reference genome using GSNAP v2020-06-30 keeping default parameters but allowing a minimum mismatch value of 2 and a minimum read coverage of $90 \%$. Finally, the gene expression levels were assessed using HTSEQ v0. 6.1. The DESeq2 v1.30.0 R package was used to process the expression with a first step of normalization using the variance-stabilizing transformation implemented in the "vst" function. The vst matrix was used to build a signed weighted co-expression network analysis implemented in the WGCNA v1.69 R package. First, genes with low overall variance $(<5 \%)$ were removed for the analysis as recommended (Langfelder \& Horvath, 2008). We fixed the "soft" threshold powers of 13 the scale-free topology criterion to reach a model fit $(|R|)$ of 0.90 . Clusters were defined using the "cutreeDynamic" function (minimum of 50 genes by cluster and default cutting height of 0.99 ) based on the topological overlap matrix, and an automatic merging step with the threshold fixed at 0.25 (default) allowed merging correlated clusters. For each cluster, we defined 
the cluster membership (kME; Eigengene-based connectivity) and only clusters showing significant correlation $(p<.01)$ to $\mathrm{pH}$ were kept for downstream functional analysis.

Signed co-expression networks were built for the host and symbiont datasets independently using the R package WGCNA with a filtering step for minimum overall variance ( $>10 \%)$ following the recommendations of Langfelder and Horvath (2008). The main goal of this analysis was to cluster genes in clusters correlated with time, temperature, and relevant physiological responses (Figure 1). Briefly, we fixed "soft" threshold powers of six and 11 for the host and symbiont datasets, respectively, using the scale-free topology criterion to reach a model fit $(|R|)$ of 0.90 and 0.80 , respectively. The clusters were defined using the "cutreeDynamic" function (minimum of 50 genes by cluster and default cutting height $=0.99$ ) based on the topological overlap matrix, and an automatic merging step with the threshold fixed at 0.25 (default) allowed us to merge correlated clusters. For each cluster, we defined the cluster membership (kME; Eigengene-based connectivity), and only statistically significant $(p<.05)$ clusters were conserved for downstream functional analysis (Figure 1).

\section{8 | Statistical analysis}

All statistical analyses were performed using the R software v4.0.3, and the threshold of statistical significance was fixed at 0.05 unless specifically stated. Relationships between dependent variables and average $\mathrm{pH}$ recorded during the exposure period (or the incubation period for net calcification and respiration rates) were computed using regression models. Dependent variables were biometrics (shell length, total body weight, and growth), physiological rates (ingestion, net calcification and respiration), biochemistry (lipid reserves, carbohydrates), and gene expression. Each gene included in the WGCNA clusters were individually tested against $\mathrm{pH}$. Fatty acids were summarized using principal component analysis and separated into two groups according to their correlation with first principal component (positive or negative). Each group was then summed and tested against $\mathrm{pH}$. Piecewise, linear and log-linear regression models were tested and compared for each individual variable (or set of variables). In each case, the model that had the highest $R^{2}$, the lowest Akaike and Bayesian information criteria (AIC, BIC) and the lowest residual sum of squares was selected. For each piecewise regression model, we estimated the tipping point, defined as the values of the $\mathrm{pH}$ where the dependent variables tip, by implementing the bootstrap restarting algorithm (Wood, 2001). For physiological rates, we also determined the critical point defined as the $\mathrm{pH}$ at which the dependent variable was equal to zero. Normality of residual distribution was tested using Shapiro-Wilk test and homogeneity of variances was graphically checked. Significance of each slope was tested according to Student's $t$ test. Piecewise regression models were built using the segmented v1.3-4 R package.

For transcriptomic analysis, only genes that are significantly correlated to $\mathrm{pH}$ were tested among the retained clusters (Pearson correlation). The frequency distribution of $\mathrm{pH}$ tipping point values was plotted for each cluster of genes. Groups of genes that exhibit neighboring tipping points with distribution frequencies $>5 \%$, were grouped together and used for GO enrichment analysis using GOAtools v0.7.11 (Klopfenstein et al., 2018), implemented in the Github repository "go_enrichment" (https://github.com/enormandeau/ go_enrichment) and the go-basic.obo database (release 2019-03-19) with Fisher's exact tests. Only significant GO terms that included a minimum of three genes and with Bonferroni adjusted $p<.01$ were kept. For complementarity with previous studies, we also specifically examined the genes that are commonly reported as involved in the calcification process and in the formation of the organic matrix of the shell and periostracum (File S1).

\section{3 | RESULTS}

\section{1 | Acclimation of oysters to 15 different $\mathrm{pH}$ conditions}

During the experiment, $\mathrm{pH}$ levels in the oyster tanks were stable and reached the targeted values, except for the lowest $\mathrm{pH}$ condition that was $6.5 \pm 0.3$ instead of 6.4 (Note S1, Table S2, Figure S2). The effects of acidification were clearly visible at the end of the experiment on the color and the size of the shells, as shown in Figure 1. Shell pigmentation apparently decreased with decreasing $\mathrm{pH}$. Total body weight and shell length of oysters ranged from $0.4 \pm 0.1$ to $2.0 \pm 0.8 \mathrm{~g}$ and from $12.9 \pm 2.1$ to $25.4 \pm 4.5 \mathrm{~mm}$ respectively (mean $\pm \mathrm{SD}$; Figure 2a, Figure S3).
FIGURE 1 Oysters exposed to 15 $\mathrm{pH}$ conditions for 23 days. Five oysters were selected from each condition, and sorted from the smallest to the biggest. Corresponding pH (total scale) and saturation states of seawater with respect to calcite $\left(\Omega_{\mathrm{CA}}\right)$ are shown [Colour figure can be viewed at wileyonlinelibrary.com]

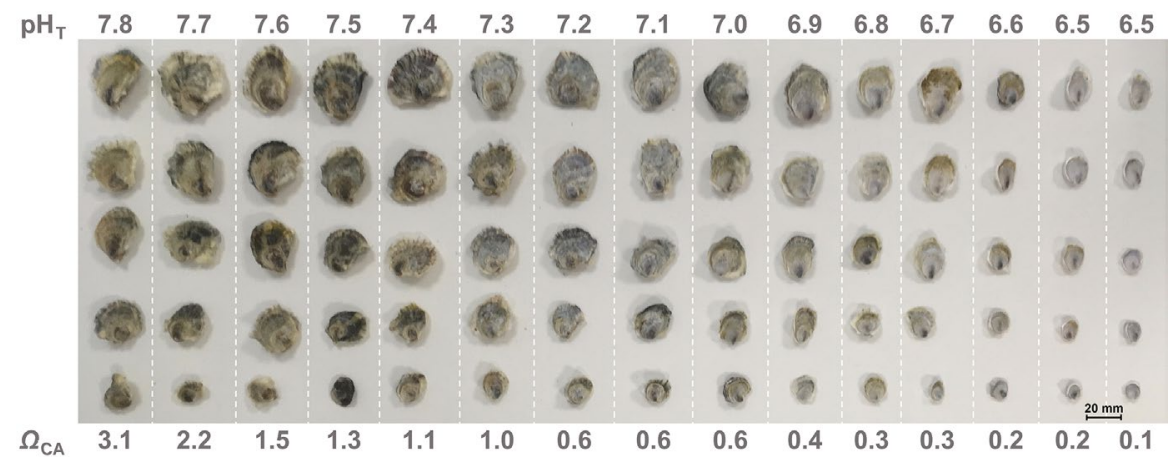


(a)
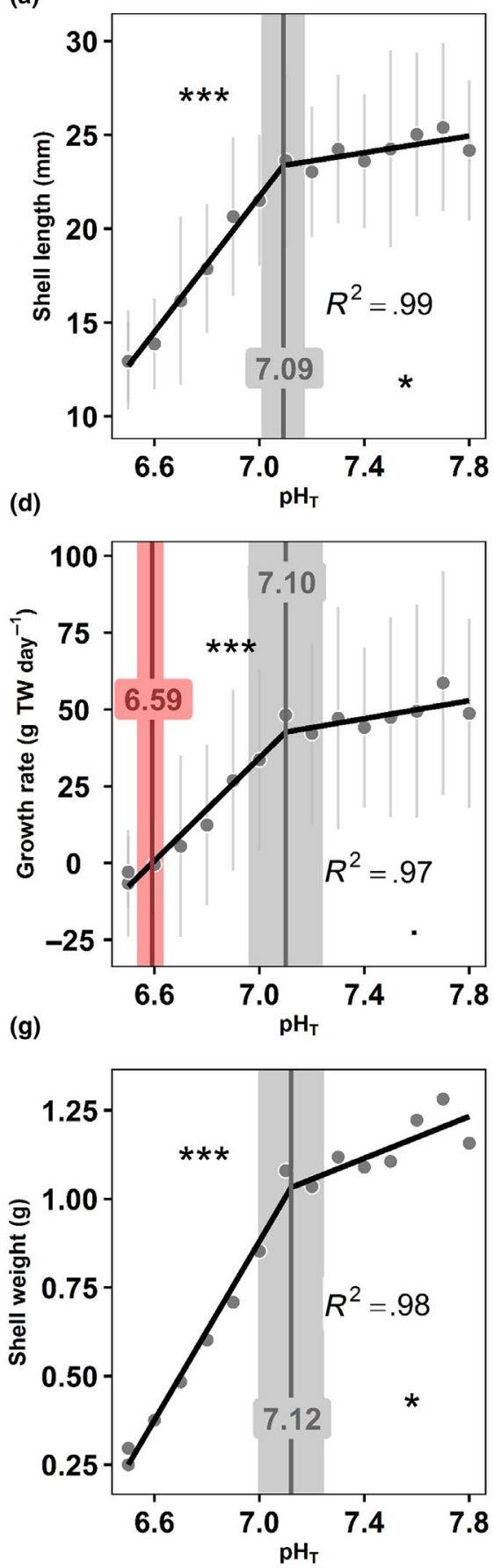

(b)

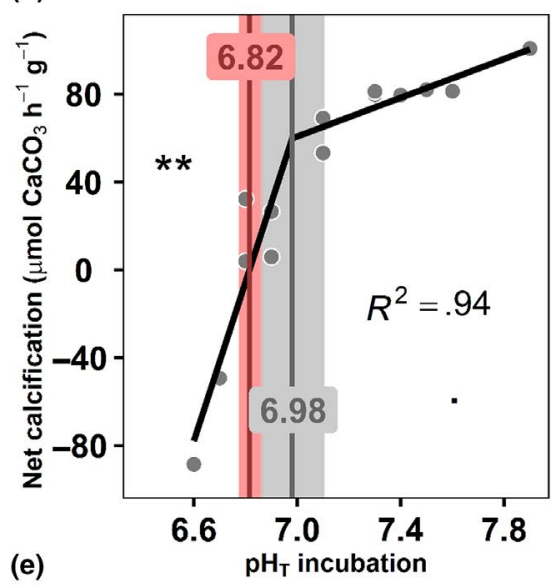

(e)
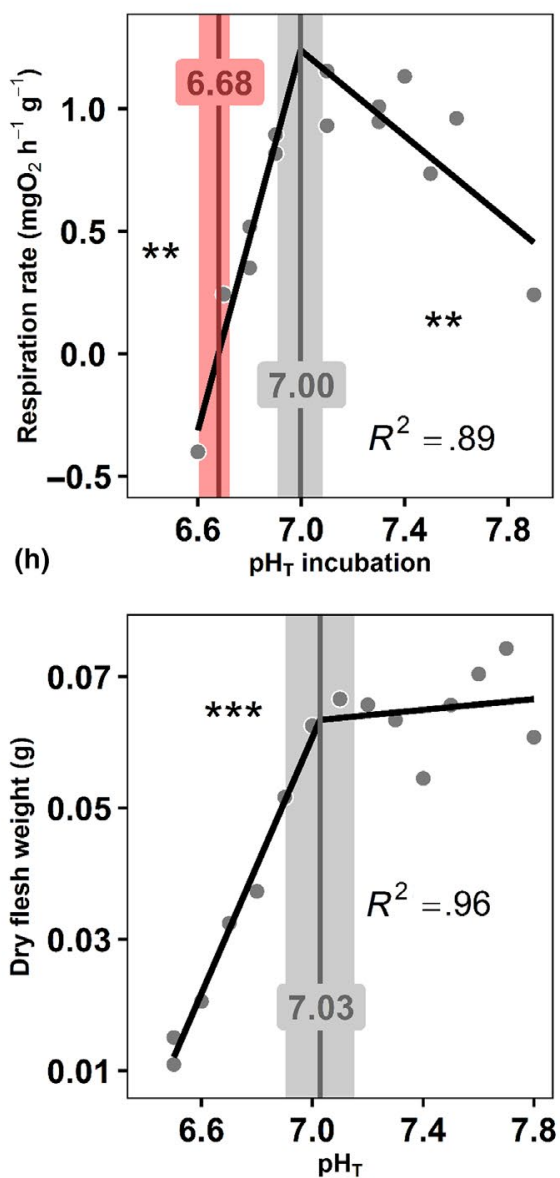

(c)
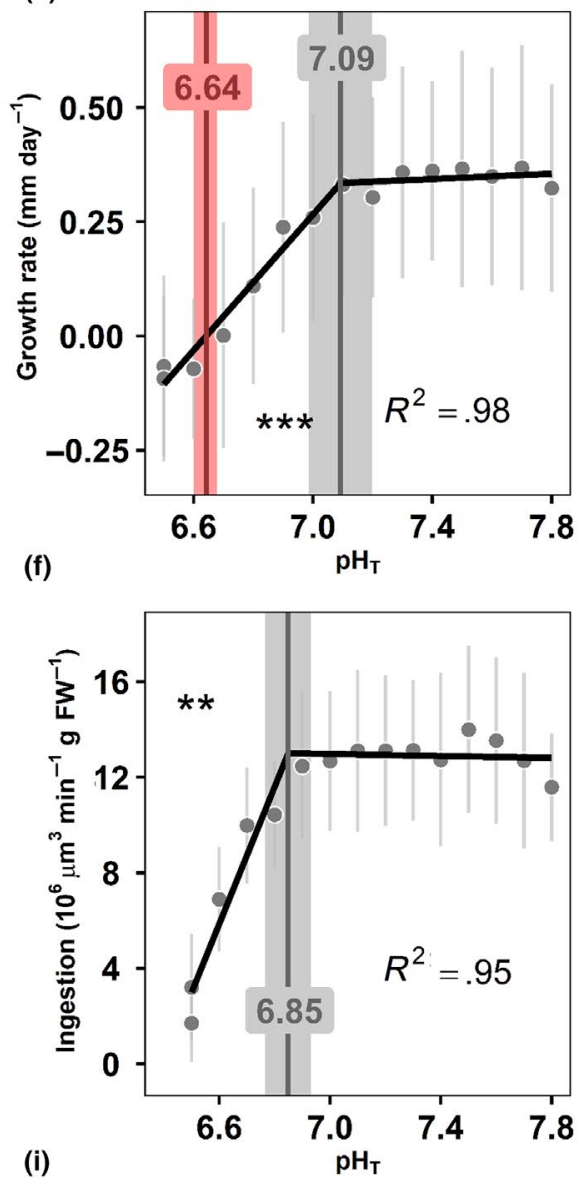

(i)

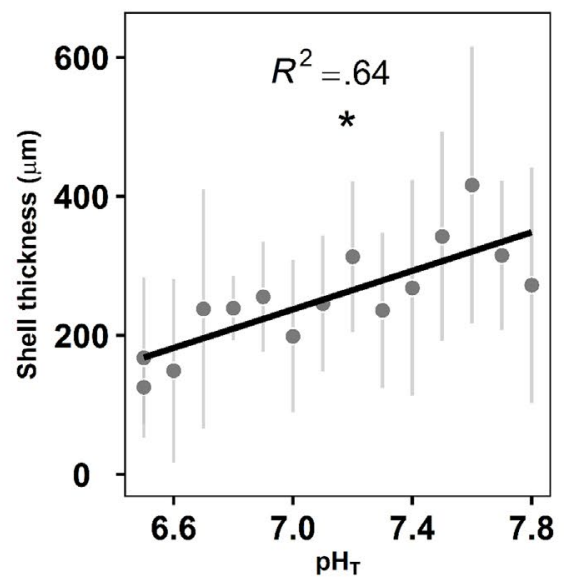

FIGURE 2 Biometry and physiological rates of oysters as a function of pH (total scale). (a) Shell length, (b) net calcification, (c) growth rate in shell length, (d) growth rate in total body weight (TW), (e) respiration rate, (f) ingestion rate, (g) shell weight, (h) dry flesh weight, and (i) minimal shell thickness. Data are means \pm SD when available. Tipping points and critical points and their $95 \%$ confidence intervals are shown in gray and red, respectively. The significance levels of the slopes are presented using symbols $\left(p<.001^{* * *},<.01^{* *},<.05^{*},<0.1\right.$. $[$ Colour figure can be viewed at wileyonlinelibrary.com]

\section{2 | Most macro-physiological traits tip at low pH values between 7.1 and 6.9}

We measured biometric parameters like the length, thickness, and weight of the shell and the total body weight and the dry flesh weight at the end of the 23-day exposure to the 15 different $\mathrm{pH}$ conditions. We calculated growth rates for shell length and total body weight, and we measured physiological rates like calcification, ingestion, and respiration rates. From these data, we identified an overall tipping point for macro-physiological traits at $\mathrm{pH} \sim 7.1-6.9$ below which they declined sharply (Figure $2 a-h)$. Calcification rate and growth rates exhibited critical points at pH 6.8 and 6.6, respectively, below which they became negative and turned to net dissolution of the shell and weight and length losses (Figure 2b-d). Concomitantly, respiration 
rate was arrested at $\mathrm{pH} 6.7$ and ingestion rate was near-zero at $\mathrm{pH}$ 6.5 (Figure 2e,f).

\section{3 | Shell parameters and respiration rate are impacted above tipping point}

Although macro-physiological traits were generally unaffected by reductions in $\mathrm{pH}$ above tipping points, this was not the case for shell length, shell weight, and respiration rate. Both shell parameters, indeed, decreased with decreasing $\mathrm{pH}$ while the respiration rate increased before reaching the tipping point (Figure 2a,e,g). In addition, the shell thickness was the only parameter that decreased linearly over the entire $\mathrm{pH}$ range without demonstrating a measurable tipping point (Figure 2i).

\subsection{A major remodeling of membrane lipids occurs at $\mathrm{pH} 6.9$}

To provide an in-depth characterization of the reaction norms at the whole organism level, we aimed to link the oyster reaction norm established for the macro-physiological traits described previously to the molecular responses of oysters. We first analyzed the fatty acid composition of membrane lipids that play an important role in exchanges between intracellular and extracellular compartments. Principal component analysis of all fatty acids showed that the first axis (PC1) alone explained $66 \%$ of the total variance in relation to $\mathrm{pH}$ (Figure 3a). The set of fatty acids was reduced to two terms defined by the sums of fatty acids that correlated with PC1 either positively or negatively, and each term was plotted against pH (Figure 3b,c). Positively correlated fatty acids mainly consisted of docosahexaenoic acid (DHA, 22:6n-3) and palmitic acid (PA, 16:0) contributing $43 \%$ and $14 \%$, respectively, to PC1 (Table S3). This group of fatty acids exhibited a tipping point at $\mathrm{pH} 6.9$, below which their contribution to membranes decreased markedly (Figure $3 \mathrm{~b}$ ). In contrast, the contribution to membrane of the fatty acids that were negatively correlated with PC1 increased markedly below $\mathrm{pH}$ 6.9. These negatively correlated fatty acids consisted of arachidonic acid (ARA, 20:4n-6), eicosapentaenoic acid (EPA, 20:5n-3), and nonmethylene interrupted fatty acids $\left(22: 2 \mathrm{NMI}_{\mathrm{i}, \mathrm{j}}\right)$, which contributed $12 \%, 6 \%$ and $6 \%$, respectively, to PC1 (Figure 3c) (Table S3).

\section{5 | Expression of most genes shows tipping points at $\mathrm{pH} 7.3-6.9$}

To further assess the molecular effects of $\mathrm{pH}$ change, we compared the transcriptome responses of oysters exposed to the 15 $\mathrm{pH}$ conditions for 23 days using RNA-seq. To do this, we first clustered the differentially expressed genes that co-vary together using WGCNA analysis and retained the clusters that were correlated with $\mathrm{pH}$ (Table S4). Then, we plotted the frequency distribution of $\mathrm{pH}$ tipping point for each cluster of genes (Figure 4). Owing to this original method, we found that 1054 genes, distributed in three clusters, showed linear (or log-linear) or piecewise regression with $\mathrm{pH}$ (Table S4). Among them, 49\% showed tipping points at $\mathrm{pH}$ 7.3-6.9 (Figure $4 a-c)$. Expression level of most genes were unchanged between $\mathrm{pH}$ conditions down to the $\mathrm{pH}$ tipping point, below which it increased for genes in clusters 1 and 2 (Figure 4a,b), or decreased for genes in cluster 3 (Figure 4c). Some genes linearly increased for clusters 1 and 2, or decreased for cluster 3 with decreasing $\mathrm{pH}$.

Gene ontology (GO) analysis showed that most of the genes from cluster 1 (42\%) exhibited tipping points at $\mathrm{pH}$ 7.3-6.9 (Figure 4a) and were associated with $\mathrm{GO}$ terms corresponding to the regulation of RNA-transcription, cellular metabolism, macromolecule biosynthesis, and negative regulation of cell-cell adhesion (Table 1). The expression of another group of genes from cluster 1 (14\%) increased linearly (or log-linearly) with decreasing $\mathrm{pH}$ and was associated with GO terms corresponding to GTP-binding, GTPase activity, and ribonucleotide metabolism (Table 1). The expression of most of the genes from cluster 2 (44\%) exhibited tipping points at $\mathrm{pH}$ 7.3-7.0, whereas another large group of genes (18\%) increased linearly (or log-linearly) with decreasing $\mathrm{pH}$ (Figure 4b). These genes were associated with (a)

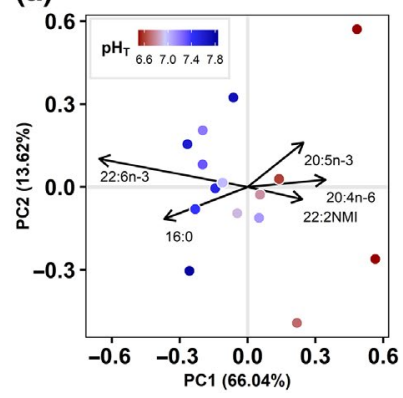

(b)

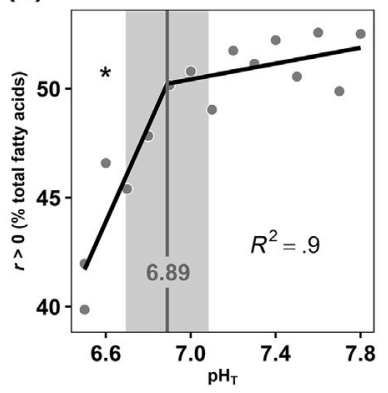

(c)

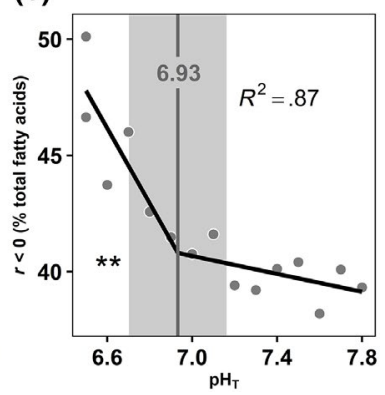

FIGURE 3 Membrane fatty acid (FA) composition of oysters as a function of pH (total scale). (a) Principal component analysis of polar fatty acid classes for oysters ( $n=15$ pools of five oysters) exposed to $15 \mathrm{pH}$ levels. Arrows represent fatty acids contributing to more than $5 \%$ of the first principal component (PC1). Individuals are colored according to the average $\mathrm{pH}$. Contribution to membrane of the sum of fatty acids that are (b) positively or (c) negatively correlated to PC1 as a function of $\mathrm{pH}$. Tipping points and their $95 \%$ confidence intervals are shown in gray. The significance levels of the slopes are presented using symbols $\left(p<.001^{* * *},<.01^{* *},<.05^{*},<.1\right.$.) [Colour figure can be viewed at wileyonlinelibrary.com] 

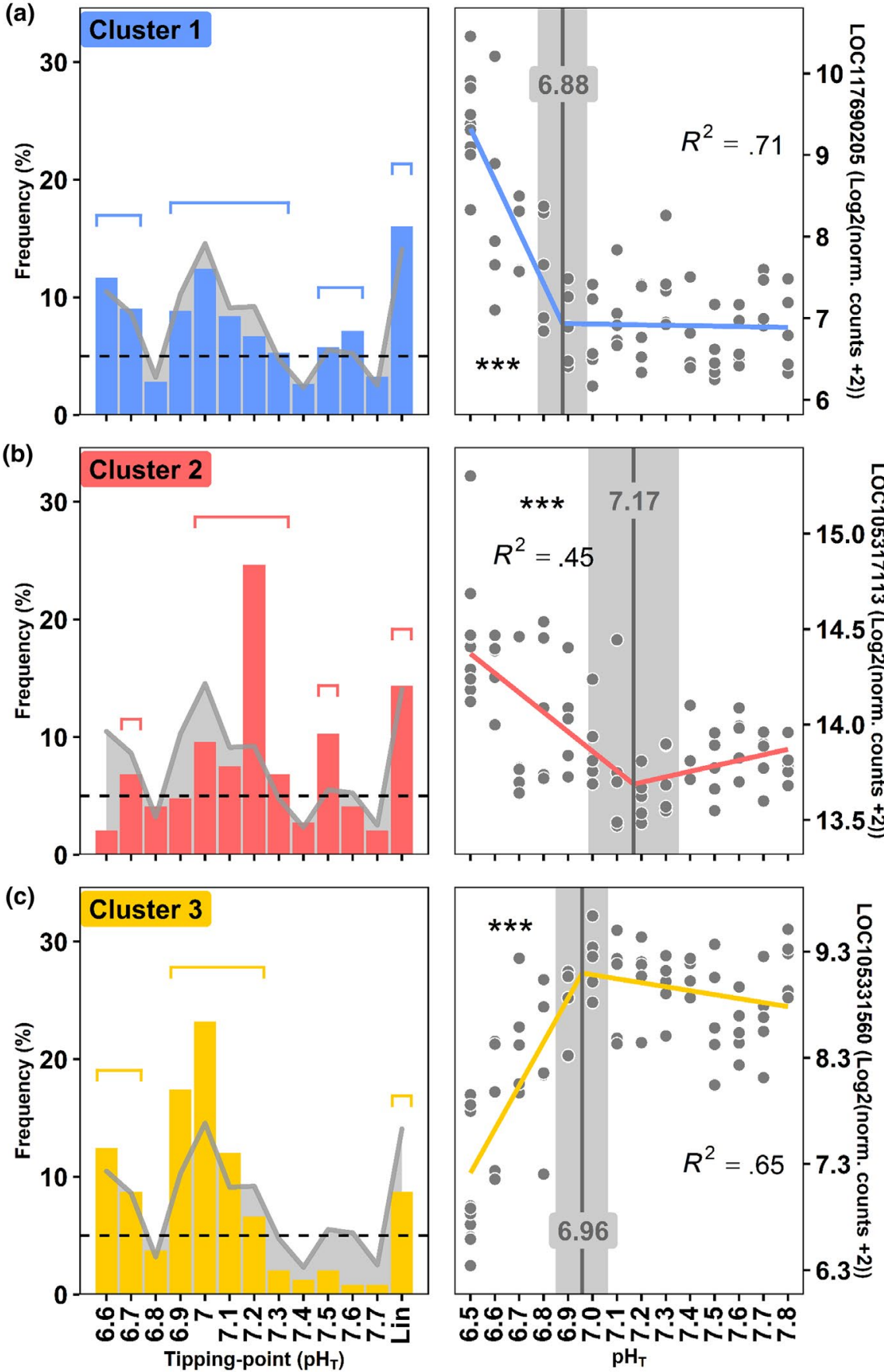

FIGURE 4 Tipping points of oyster transcriptome. (a-c) Frequency distribution of tipping point for piecewise linear relationships (left side). Linear and log-linear models (no tipping point) are under "Lin" name. Genes are grouped into three clusters of genes that covary together. The gray line indicates the distribution frequency of all genes irrespective of clusters. Groups of genes that exhibit neighboring tipping points with distribution frequencies $>5 \%$ (shown as a dotted line), were grouped together. The segments above the bars indicate the groups of genes on which $\mathrm{GO}$ analyses were conducted. In each case, the gene that best represents the cluster according to module membership, gene significance for $\mathrm{pH}$ and $R^{2}$ is presented as a function of $\mathrm{pH}$ as an example (right side). Tipping points and their $95 \%$ confidence intervals are shown in gray. The significance levels of the slopes are presented using stars $\left(p<.001^{* * *}, p<.01^{* *}, p<.05^{*}\right)$. Gene names are as follows: LOC117690205: monocarboxylate transporter 12-like, LOC105317113: 60S ribosomal protein L10a, LOC105331560: protocadherin Fat 4 [Colour figure can be viewed at wileyonlinelibrary.com]
GO terms corresponding to ribosome synthesis, RNA-binding, translation, and protein/amino acid synthesis (Table 1). The expression of $62 \%$ of the genes from cluster 3 exhibited tipping points at $\mathrm{pH}$ 7.2-6.9 and decreased thereafter (Figure 4c). These genes were associated with GO terms corresponding to ion transport and more specifically to transmembrane cation transport (Table 1).

\subsection{Expression of genes related to biomineralization shows tipping point at $\mathrm{pH}$ 7.1-6.9}

We specifically examined the genes that are commonly reported in the scientific literature as being involved in the calcification process and in the formation of the organic matrix of the shell and periostracum. We found that the expression of $60 \%$ of the 38 genes involved in the calcification process that were retained by our models showed pH tipping points between 6.9 and 7.1 (Table 2). These genes encode for calcium-binding proteins, $\mathrm{Ca}^{2+}$ signaling pathway, amorphous calcium carbonate-binding proteins and ion transmembrane transporters. Most of these genes decreased below the tipping point $(n=14)$ while others increased $(n=8)$. The expression of genes associated with the regulation of the synthesis of the shell organic matrix and the periostracum $(n=11)$ generally increased with decreasing $\mathrm{pH}$ (Table 2). The relationships were log-linear $(n=3)$ or piecewise $(n=8)$.

Among these 38 genes, the family of genes that are the most represented are coding for acetylcholine receptors, monocarboxylate 
TABLE 1 Gene ontology term enrichment and tipping point

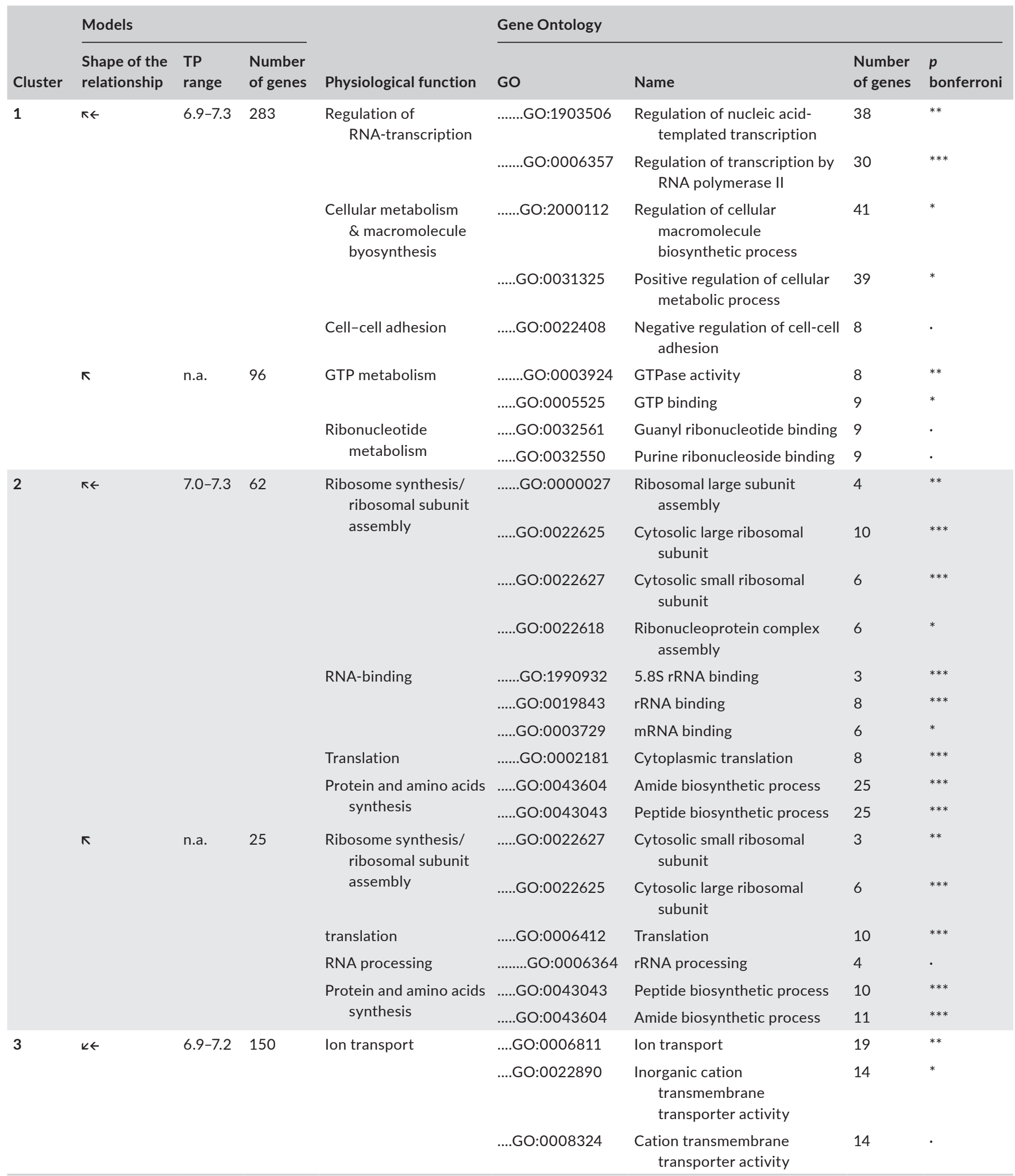

Note: Model characteristics, physiological function and gene ontology for each cluster. For each GO term, the $p$-value of Bonferroni test is displayed using symbols $\left(p<.001^{* * *},<.01^{* *},<.05^{*},<.1\right.$.).

Abbreviation: TP, tipping point.

transporters, and tyrosinase synthesis (Table 2). The expression of four genes coding for acetylcholine receptors decreased below tipping points at $\mathrm{pH}$ 6.9-7.0. The expression of five genes coding for monocarboxylate transporters increased with decreasing $\mathrm{pH}$, and four of them showed $\mathrm{pH}$ tipping points between 7.3 and 6.6. The expression of four genes associated to tyrosinase synthesis early 
WI LEY- Global Change Biology

TABLE 2 Tipping points of genes related to calcification and production of the shell organic matrix

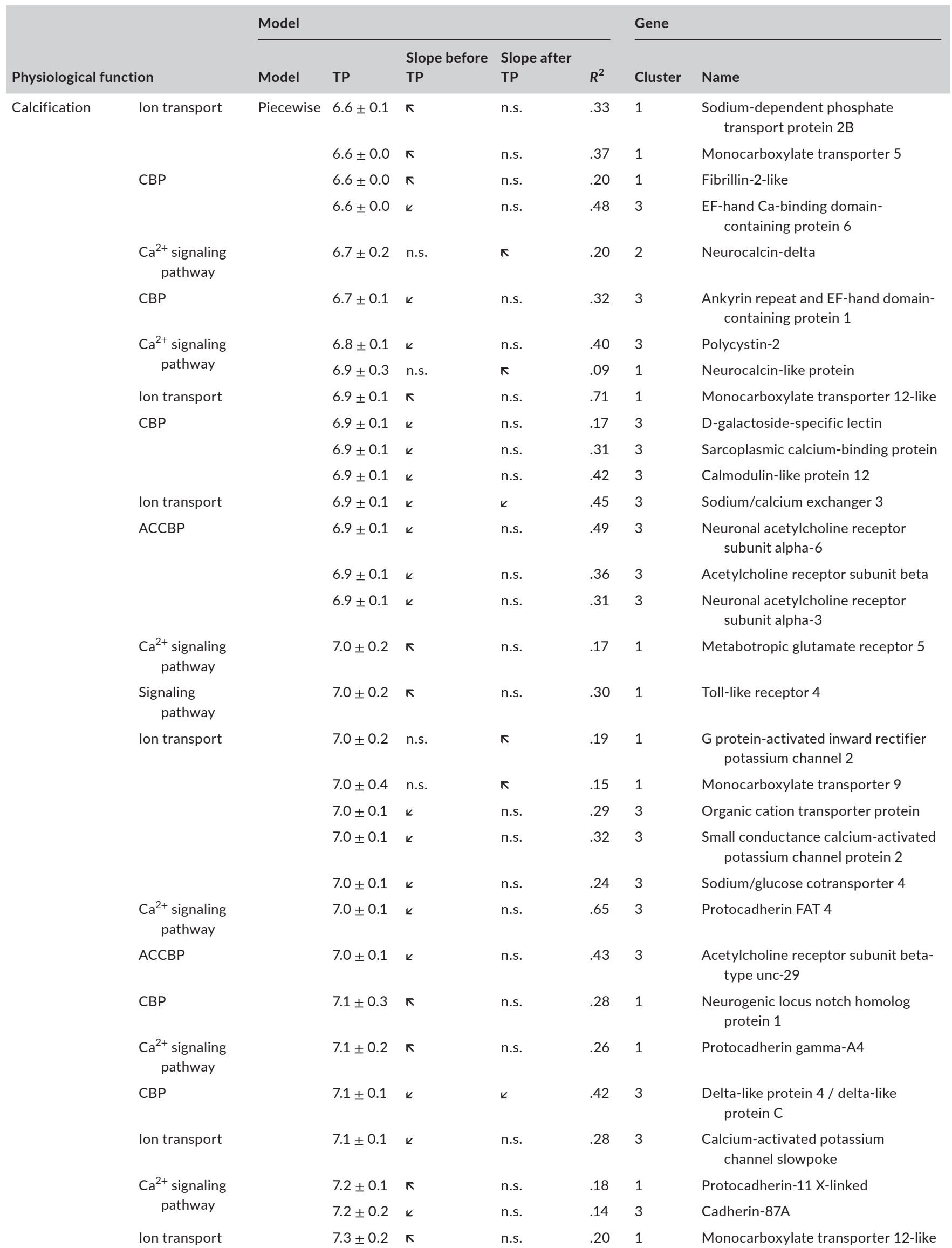


TABLE 2 (Continued)

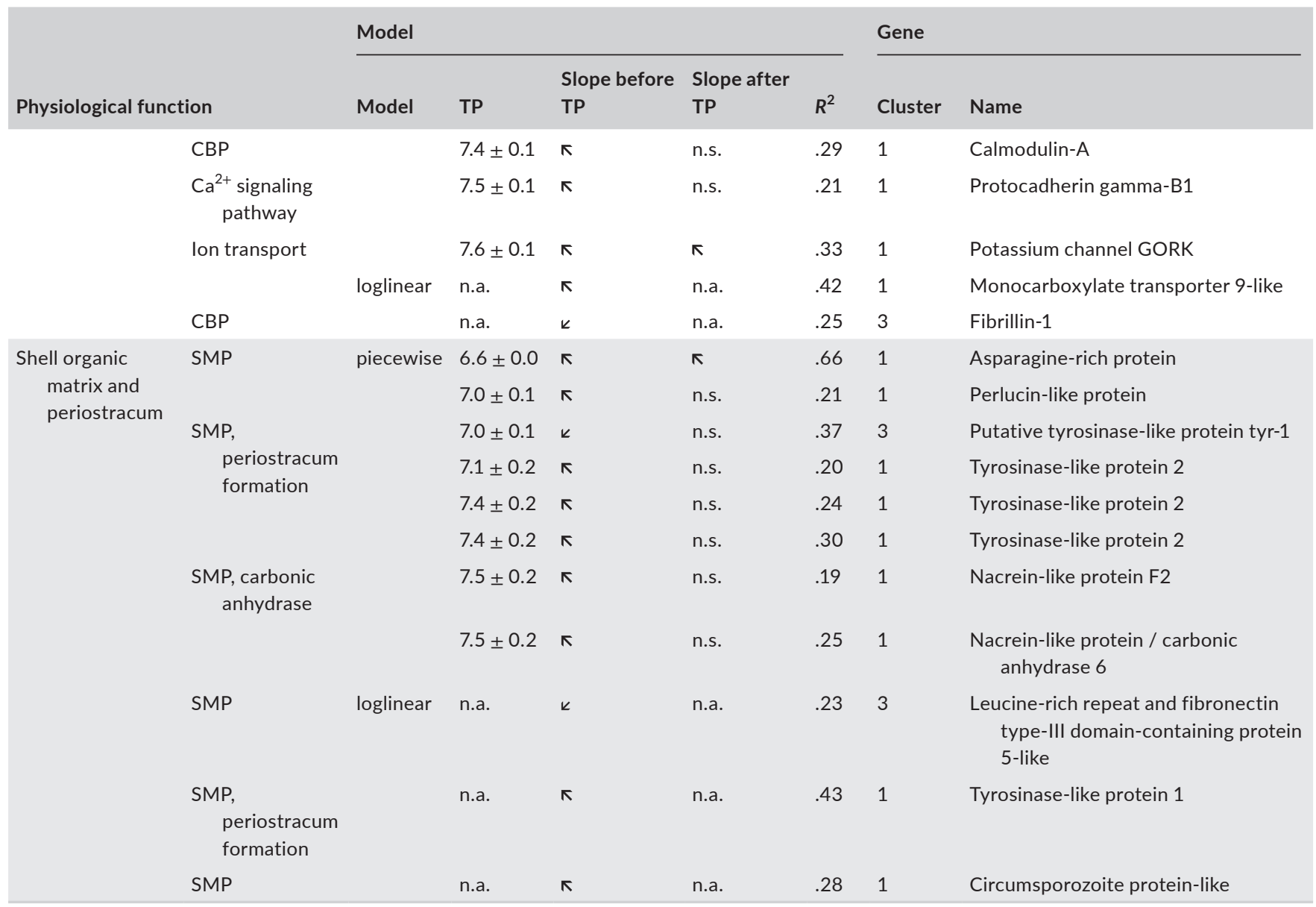

Note: Model characteristics and physiological function are reported for each gene. The slope inclination is displayed using arrows only if it is significant according to Student $t$ tests $(p<.05)$.

Abbreviations: ACCBP, amorphous calcium carbonate-binding proteins; CBP, calcium-binding proteins; SMP, shell matrix proteins; TP, tipping point.

increased with decreasing $\mathrm{pH}$ and three of them showed tipping points between $\mathrm{pH} 7.4$ and 7.1 .

\section{4 | DISCUSSION}

Here, we provide the first reaction norm of juvenile oyster C. gigas assessed by combining macro-physiological traits and micro-molecular characteristics. This novel approach applied to juvenile oysters exposed to a wide range of $\mathrm{pH}$ conditions revealed that macrophysiological parameters such as growth, calcification, food intake, and respiration exhibited $\mathrm{pH}$ tipping points that coincide with a major reshuffling in membrane lipids and transcriptome that was previously unappreciated, but others like shell parameters seemed uncoupled from global effects (Figure 5). This comprehensive view of the oyster response to $\mathrm{pH}$ sheds new light on adaptation capacity of this species to OA. We, indeed, identify low tipping points for most physiological traits that suggest the species is robust to OA, but reveal sensitivity of shell parameters above the tipping points that potentially impact animal fitness. We therefore determine the true sensitivity of oyster to $\mathrm{pH}$ and identify the most relevant and sensitive response variables.
We first identify a global tolerance threshold for juvenile $C$. gigas at $\mathrm{pH}$ 6.9-7.3, corresponding to the tipping points identified for the majority of the examined parameters. In line with this, several studies based on IPCC scenario assumed the existence of tipping points below $\mathrm{pH}$ 7.5-7.4 for growth, calcification, acid-base equilibrium, and reproduction in oysters and mussels (Boulais et al., 2017; Fitzer et al., 2014; Lannig et al., 2010). Our results are also in agreement with previous studies showing that there are no significant changes in growth, respiration, mortality, metabolic rate, ion regulation, energy reserves, gene expression, and fatty acid profile in juveniles and adults of C. gigas for $\mathrm{pH}$ values above 7.3. (Clark et al., 2013; Lannig et al., 2010; Lemasson et al., 2018; Timmins-Schiffman et al., 2014; Wang et al., 2020). Below tipping points, growth, calcification, respiration, and feeding rate decreased markedly, likely reflecting increasing maintenance cost up until reaching critical points that are representative of metabolic depression (Michaelidis et al., 2005; Sokolova, 2021). It is noteworthy that longer exposure time might have revealed an impact of the $\mathrm{pH}$ on survival or reproduction, two important parameters for fitness. Survival should be compromised below the tipping point as the animal shift to metabolic depression, that is, a short-term survival strategy (Michaelidis et al., 2005). 


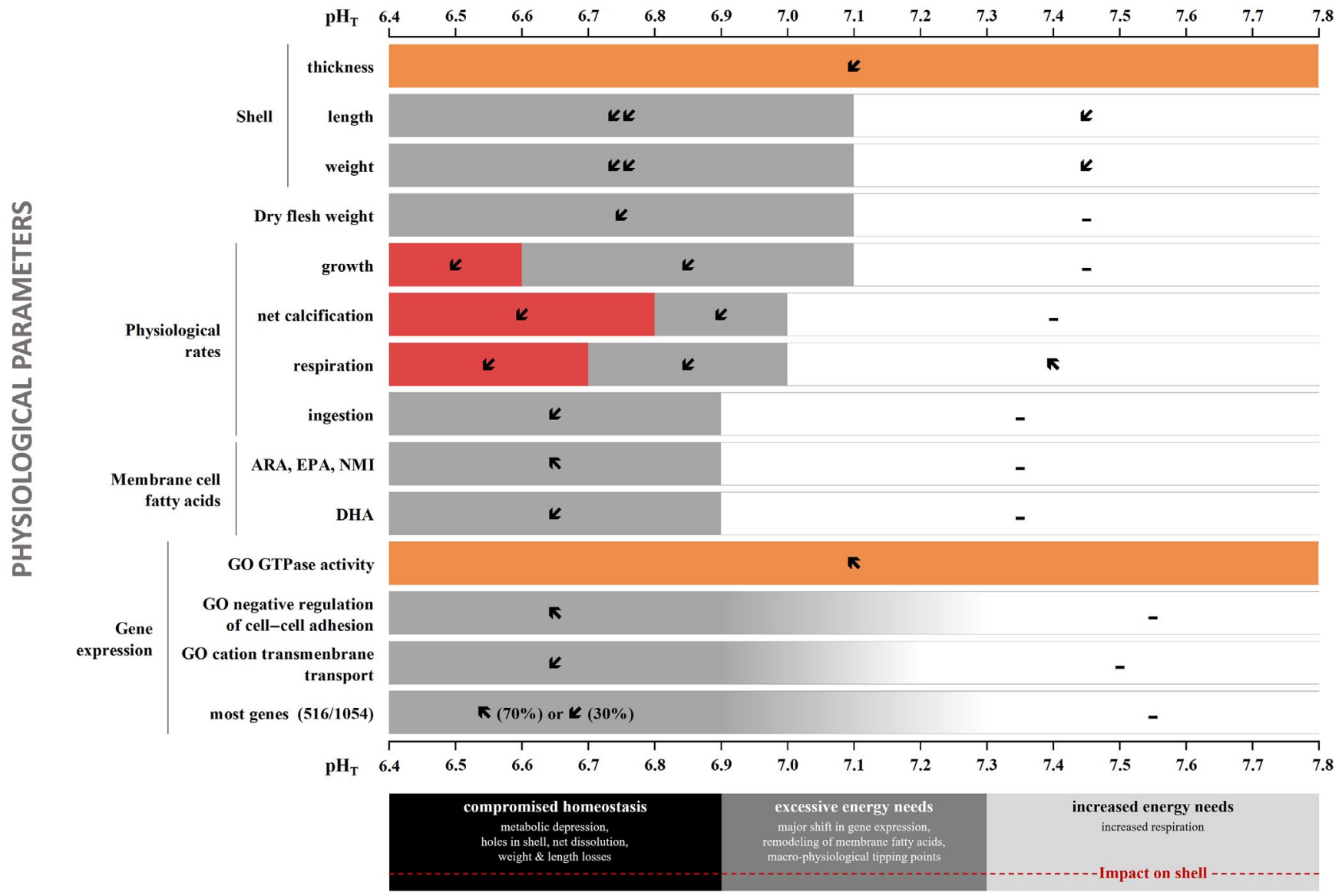

GLOBAL PHYSIOLOGICAL RESPONSE

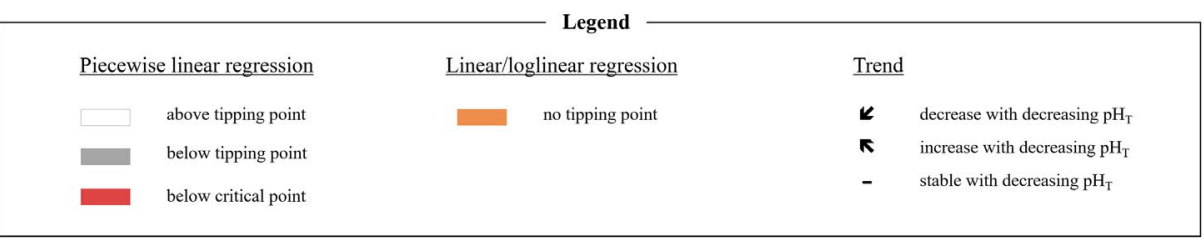

FIGURE 5 Graphical summary of the reaction norm of juvenile oysters Crassostrea gigas over a wide range of pH conditions. ARA, arachidonic acid; DHA, docosahexaenoic acid, EPA, ecosapentaenoic acid; GO, gene ontology term; NMI, nonmethylene interrupted [Colour figure can be viewed at wileyonlinelibrary.com]

The tipping points we determined at $\mathrm{pH} 7.3-6.9 \mathrm{pCO}_{2} \sim 2600-$ $8200 \mu \mathrm{atm})$ are well below IPCC projections for 2100 in open ocean waters ( $\mathrm{pH}=7.8$ according to scenario RCP 8.5 IPCC, 2019). However, acidification events with $\mathrm{pH}$ values as low as 7.4-7.0 $\left(\mathrm{pCO}_{2}>3000 \mu \mathrm{atm}\right)$ currently occur transiently in estuarine ecosystems in relation to eutrophication and hypoxia (Frankignoulle et al., 1996; Melzner et al., 2013; Proum et al., 2017; Wallace et al., 2014) and may explain why the physiological tipping point of oysters is so low. These acidification events are expected to become increasingly frequent and intense in the future (IPCC, 2019), such that the physiological tipping points defined here for juvenile oysters may be reached.

This point outs the importance of tipping point for coastal management and conservation in a changing world. Tipping point is valid for a whole population regardless of habitat. Here we used juveniles that originate from a large genetic pool and C. gigas is a weakly genetically structured species (Meistertzheim et al., 2013). However, it was recently shown that wild and domesticated oysters populations vary in their adaptive response to OA (Durland et al., 2021). We, therefore, need to verify that $\mathrm{pH}$ tipping points defined in our study are valid in genetically differentiated populations before integrating them in biogeographic models of species distribution. Finally, tipping point is a single value that reflects susceptibility to stressors that is easily communicable to end-users and society (Bednaršek et al., 2019, 2021).

We show here that shell parameters, that is, thickness, weight, and length, were altered as soon as $\mathrm{pH}$ decreased from ambient levels, as already reported for many shellfish species (Byrne \& Fitzer, 2019). Shell thickness is generally related to shell strength and, therefore, with protection against predation and resistance to mechanical stress related to wave exposure and aquaculture processes. Thus, moderate acidification increases predation risk of young $C$. 
gigas through reduction of shell strength (Wright et al., 2018). We also find that respiration rate first increased when $\mathrm{pH}$ decreased, suggesting that metabolism was readily impacted. However, body condition (dry flesh weight) and energy reserves (TAG-ST and carbohydrate, Figure S4) were not affected by $\mathrm{pH}$, likely because oysters were fed ad libitum (Leung et al., 2019; Thomsen et al., 2013). Finally, we report here a linear increase in the expression level of genes related to GTPase activity and GTP binding, which are characteristics of stress response in Crassostrea spp. (Yan et al., 2018). Overall, these changes suggest that longer exposure to moderate acidification (above tipping point) could impair overall oyster fitness.

We further show that this reduction in shell parameters was not related to metabolic depression or to changes in net calcification or global gene expression. In contrast, a recent meta-analysis on $C$. gigas suggests that $\mathrm{OA}$ induces a reduction in shell thickness that is related to an overall transcriptional change inducing metabolic depression and alteration of calcification rate (Ducker \& Falkenberg, 2020). Here, we revisit these assumptions and find in agreement with other prior studies that no metabolic disruptions occurred while shell strength and thickness decreased at pH 7.3-7.7 (TimminsSchiffman et al., 2014; Wright et al., 2018).

Concomitantly, a delamination of the periostracum, the organic coat covering the shell, may have occurred at $\mathrm{pH}$ levels above the tipping point, probably altering shell protection. This was supported by an apparent increase in shell bleaching and expression of four genes coding for tyrosinase-like proteins. Tyrosinases are involved in periostracum synthesis and the increase in expression of their related genes is often considered as a mechanism to limit the damage to the periostracum and the corrosion of the shell in reaction to OA (Hüning et al., 2013). Delamination of the periostracum due to moderate OA was frequently associated with alteration of shell properties such as weakening and thinning (Alma et al., 2020; Auzoux-Bordenave et al., 2019; Bressan et al., 2014; Coleman et al., 2014; Peck et al., 2016, 2018; Zhao et al., 2020). Our results agree with the idea that OA is more a dissolution problem than a biomineralization problem (Rajan et al., 2021).

This investigation of tipping points at the micro-scale also provides new insights on the physiological response of oysters to OA. For the first time, we find a major remodeling of membrane lipids in response to $\mathrm{OA}$ and observed a tipping point at $\mathrm{pH}$ 6.9. This remodeling consisted of decreasing the long chain PUFA DHA (22:6n-3) that is essential for growth and survival (Knauer \& Southgate, 1999; Langdon \& Waldock, 1981), at the benefit of eicosanoid precursors (ARA, 20:4n-6 and EPA, 20:5n-3) involved in the stress response (Delaporte et al., 2003). Because membrane fatty acid composition influences the activity of transmembrane proteins involved in ion transport (Hazel \& Williams, 1990; Hochachka \& Somero, 2002), it could also have been related to regulation of acid-base homeostasis and perhaps calcification under OA.

In line with this, we find an overall decrease in expression of genes related to cation transmembrane transport below tipping points at $\mathrm{pH}$ 6.9-7.2 that can be related to alteration of calcification and acid-base homeostasis (Zhao et al., 2020). Concomitantly, we observe an overall decrease in the expression of genes coding for proteins involved in the regulation of calcification though calcium signaling pathway, calcium homeostasis, calmodulin signaling pathway, and regulation of calcium carbonate crystal growth (Feng et al., 2017; Wang et al., 2017; Zhao et al., 2020).

In our analysis, we also identify families of genes that must play an important role in oyster response to OA. Among these genes, we identify four genes coding for acetylcholine receptors that are known for regulating and ordering the formation of the shell micro-structure (Feng et al., 2017). We also find five monocarboxylate transporters coding genes, members of a family of proteins that act as co-transporters of protons $\mathrm{H}^{+}$, that may be involved in the regulation of acid-base homeostasis and calcification process (Tresguerres et al., 2020; Wang et al., 2020). These proteins also co-transport monocarboxylates such as lactate or pyruvate and were reported to be involved in the stress response of oysters through induction of anaerobiosis under metabolic depression (Ertl et al., 2019).

In conclusion, we show that juvenile $C$. gigas have a broad tolerance to $\mathrm{OA}$, exhibiting tipping points around $\mathrm{pH}$ 7.3-6.9 for most parameters (Figure 5). Nonetheless, we observe that shell parameters change as soon as $\mathrm{pH}$ drops, well before tipping points are reached, suggesting animal fitness is likely to be affected. This thus raises concerns about the future of natural and farmed oyster populations in a high- $\mathrm{CO}_{2}$ world. This new framework for identification of tolerance threshold in organisms represents a breakthrough in the field of global change research. It was made possible by (1) combining reaction norm assessment and thorough molecular and biochemical analyses of animal responses, and (2) developing a procedure to analyze and synthesize omics data measured over an environmental range.

We believe that such an integrative and holistic approach could now be applied to other organisms and integrate intraspecific variation, life-stages, generations, and other stressors such as temperature, nutrition, pollutants, or oxygen levels. Although this approach requires significant financial resources, it allows to determine the true sensitivity of a species to a stressor and to identify the most relevant and sensitive response variables to study in the future.

\section{ACKNOWLEDGMENTS}

We are grateful for K. Lugue, J. Veillet, C. Quéré, V. Le Roy, and I. Queau for their participation to data recording and the Ifremer staff for their involvement in oyster and algae production. We thank J. Thebault and E. Dabass for their advices in shell analysis. We are also grateful for G. Le Moullac for project conception and funding. This work was funded by the Ocean Acidification Program of the French Foundation for Research on Biodiversity (FRB; www.fondationb iodiversite.fr) and the French Ministère de la transition écologique.

\section{CONFLICT OF INTEREST}

The authors declare no competing interests. 


\section{AUTHOR CONTRIBUTIONS}

Mathieu Lutier, Carole Di Poi, and Fabrice Pernet designed and conducted the experiment. All authors analyzed the data. Mathieu Lutier performed statistics. Mathieu Lutier and Fabrice Pernet wrote the first draft of the document, and all authors contributed and accepted it. Fabrice Pernet and Jérémy Le Luyer obtained the funding. This work is part of the PhD thesis of Mathieu Lutier.

\section{DATA AVAILABILITY STATEMENT}

RNA-seq data have been made available through the SRA database (BioProject accession number PRJNA735889). Other data analyzed during this study are included in this published article and its supplementary information files or available through the SEANOE database https://doi.org/10.17882/83294 (Lutier et al., 2021). Complementary information is available from the corresponding authors on reasonable request.

\section{ORCID}

Mathieu Lutier (D) https://orcid.org/0000-0003-3955-9277

Carole Di Poi (D) https://orcid.org/0000-0001-7846-5287

Frédéric Gazeau (D) https://orcid.org/0000-0001-8807-4597

Jérémy Le Luyer (D) https://orcid.org/0000-0001-9409-3196

Fabrice Pernet (D) https://orcid.org/0000-0001-8886-0184

\section{REFERENCES}

Alma, L., Kram, K. E., Holtgrieve, G. W., Barbarino, A., Fiamengo, C. J., \& Padilla-Gamiño, J. L. (2020). Ocean acidification and warming effects on the physiology, skeletal properties, and microbiome of the purple-hinge rock scallop. Comparative Biochemistry and Physiology Part A: Molecular \& Integrative Physiology, 240, 110579. https://doi. org/10.1016/j.cbpa.2019.110579

Aminot, A., \& Kérouel, R. (2007). Dosage automatique des nutriments dans les eaux marines (MEDD, Editions Quae): Ifremer. https://www.quae. com/produit/924/9782759200238/dosage-automatique-desnutriments-dans-les-eaux-marines

Auzoux-Bordenave, S., Wessel, N., Badou, A., Martin, S., M'Zoudi, S., Avignon, S., Roussel, S., Huchette, S., \& Dubois, P. (2019). Ocean acidification impacts growth and shell mineralization in juvenile abalone (Haliotis tuberculata). Marine Biology, 167(1), 11. https://doi. org/10.1007/s00227-019-3623-0

Bayne, B. L. (2017). Biology of oysters (Vol. 41). Academic Press.

Bednaršek, N., Calosi, P., Feely, R. A., Ambrose, R., Byrne, M., Chan, K. Y. K., Dupont, S., Padilla-Gamiño, J. L., Spicer, J. I., Kessouri, F., Roethler, M., Sutula, M., \& Weisberg, S. B. (2021). Synthesis of thresholds of ocean acidification impacts on echinoderms. Frontiers in Marine Science, 8. https://doi.org/10.3389/fmars.2021.602601

Bednaršek, N., Feely, R. A., Howes, E. L., Hunt, B. P. V., Kessouri, F., León, P., Lischka, S., Maas, A. E., McLaughlin, K., Nezlin, N. P., Sutula, M., \& Weisberg, S. B. (2019). Systematic Review and meta-analysis toward synthesis of thresholds of ocean acidification impacts on calcifying pteropods and interactions with warming. Frontiers in Marine Science, 6. https://doi.org/10.3389/fmars.2019.00227

Boulais, M., Chenevert, K. J., Demey, A. T., Darrow, E. S., Robison, M. R., Roberts, J. P., \& Volety, A. (2017). Oyster reproduction is compromised by acidification experienced seasonally in coastal regions. Scientific Reports, 7(1), 13276. https://doi.org/10.1038/s41598017-13480-3

Bressan, M., Chinellato, A., Munari, M., Matozzo, V., Manci, A., Marčeta, T., Finos, L., Moro, I., Pastore, P., Badocco, D., \& Marin, M. G. (2014).
Does seawater acidification affect survival, growth and shell integrity in bivalve juveniles? Marine Environmental Research, 99, 136148. https://doi.org/10.1016/j.marenvres.2014.04.009

Browman, H. I. (2017). Towards a broader perspective on ocean acidification research. ICES Journal of Marine Science, 74(4), 889-894. https://doi.org/10.1093/icesjms/fsx073

Byrne, M., \& Fitzer, S. (2019). The impact of environmental acidification on the microstructure and mechanical integrity of marine invertebrate skeletons. Conservation Physiology, 7(1), 62-82. https://doi. org/10.1093/conphys/coz062

Caldeira, K., \& Wickett, M. E. (2003). Anthropogenic carbon and ocean pH. Nature, 425(6956), 365. https://doi.org/10.1038/425365a

Clark, M. S., Thorne, M. A. S., Amaral, A., Vieira, F., Batista, F. M., Reis, J., \& Power, D. M. (2013). Identification of molecular and physiological responses to chronic environmental challenge in an invasive species: The Pacific oyster, Crassostrea gigas. Ecology and Evolution, 3(10), 3283-3297. https://doi.org/10.1002/ece3.719

Coleman, D., Byrne, M., \& Davis, A. (2014). Molluscs on acid: Gastropod shell repair and strength in acidifying oceans. Marine Ecology Progress Series, 509, 203-211. https://doi.org/10.3354/ meps10887

Comeau, S., Edmunds, P. J., Spindel, N. B., \& Carpenter, R. C. (2013). The responses of eight coral reef calcifiers to increasing partial pressure of $\mathrm{CO}_{2}$ do not exhibit a tipping point. Limnology and Oceanography, 58(1), 388-398. https://doi.org/10.4319/lo.2013.58.1.0388

Cyronak, T., Schulz, K. G., \& Jokiel, P. L. (2016). The Omega myth: What really drives lower calcification rates in an acidifying ocean. ICES Journal of Marine Science, 73(3), 558-562. https://doi.org/10.1093/ icesjms/fsv075

Delaporte, M., Soudant, P., Moal, J., Lambert, C., Quéré, C., Miner, P., Choquet, G., Paillard, C., \& Samain, J.-F. (2003). Effect of a monospecific algal diet on immune functions in two bivalve speciesCrassostrea gigas and Ruditapes philippinarum. Journal of Experimental Biology, 206(17), 3053-3064. https://doi.org/10.1242/jeb.00518

Dickson, A. G., Sabine, C. L., \& Christian, J. R. (2007). Guide to best practices for ocean $\mathrm{CO}_{2}$ measurements (PICES Special Publication 3). North Pacific Marine Science Organization. https://www. ncei.noaa.gov/access/ocean-carbon-data-system/oceans/Handb ook_2007.html

Dineshram, R., Quan, Q., Sharma, R., Chandramouli, K., Yalamanchili, H. K., Chu, I., \& Thiyagarajan, V. (2015). Comparative and quantitative proteomics reveal the adaptive strategies of oyster larvae to ocean acidification. Proteomics, 15(23-24), 4120-4134. https://doi. org/10.1002/pmic.201500198

Dorey, N., Lançon, P., Thorndyke, M., \& Dupont, S. (2013). Assessing physiological tipping point of sea urchin larvae exposed to a broad range of $\mathrm{pH}$. Global Change Biology, 19(11), 3355-3367. https://doi. org/10.1111/gcb.12276

DuBois, M., Gilles, K. A., Hamilton, J. K., Rebers, P. A., \& Smith, F. (1956). Colorimetric method for determination of sugars and related substances. Analytical Chemistry, 28(3), 350-356. https://doi. org/10.1021/ac60111a017

Ducker, J., \& Falkenberg, L. J. (2020). How the pacific oyster responds to ocean acidification: development and application of a meta-analysis based adverse outcome pathway. Frontiers in Marine Science, 7(7), 398-408. https://doi.org/10.3389/fmars.2020.597441

Durland, E., De Wit, P., Meyer, E., \& Langdon, C. (2021). Larval development in the Pacific oyster and the impacts of ocean acidification: Differential genetic effects in wild and domesticated stocks. Evolutionary Applications, 14(9), 2258-2272. https://doi. org/10.1111/eva.13289

Ertl, N. G., O'Connor, W. A., \& Elizur, A. (2019). Molecular effects of a variable environment on Sydney rock oysters, Saccostrea glomerata: Thermal and low salinity stress, and their synergistic effect. Marine Genomics, 43, 19-32. https://doi.org/10.1016/j. margen.2018.10.003 
FAO. (2020). Fishery and aquaculture statistics. Global production by production source 1950-2018 (FishstatJ). In FAO fisheries and aquaculture department. https://www.fao.org/fishery/statistics/softw are/fishstatj/en

Feng, D., Li, Q., Yu, H., Kong, L., \& Du, S. (2017). Identification of conserved proteins from diverse shell matrix proteome in Crassostrea gigas: Characterization of genetic bases regulating shell formation. Scientific Reports, 7(1), 45-54. https://doi.org/10.1038/srep45754

Fitzer, S. C., Phoenix, V. R., Cusack, M., \& Kamenos, N. A. (2014). Ocean acidification impacts mussel control on biomineralisation. Scientific Reports, 4(1), 6218. https://doi.org/10.1038/srep06218

Frankignoulle, M., Bourge, I., \& Wollast, R. (1996). Atmospheric $\mathrm{CO}_{2}$ fluxes in a highly polluted estuary (the Scheldt). Limnology and Oceanography, 41(2), 365-369. https://doi.org/10.4319/ lo.1996.41.2.0365

Gazeau, F., Alliouane, S., Bock, C., Bramanti, L., López Correa, M., Gentile, M., Hirse, T., Pörtner, H.-O., \& Ziveri, P. (2014). Impact of ocean acidification and warming on the Mediterranean mussel (Mytilus galloprovincialis). Frontiers in Marine Science, 1, 62. https:// doi.org/10.3389/fmars.2014.00062

Gazeau, F., Parker, L. M., Comeau, S., Gattuso, J.-P., O'Connor, W. A., Martin, S., Pörtner, H.-O., \& Ross, P. M. (2013). Impacts of ocean acidification on marine shelled molluscs. Marine Biology, 160(8), 2207-2245. https://doi.org/10.1007/s00227-013-2219-3

Gazeau, F., Urbini, L., Cox, T. E., Alliouane, S., \& Gattuso, J.-P. (2015). Comparison of the alkalinity and calcium anomaly techniques to estimate rates of net calcification. Marine Ecology Progress Series, 527, 1-12. https://doi.org/10.3354/meps11287

Hazel, J. R., \& Williams, E. (1990). The role of alterations in membrane lipid composition in enabling physiological adaptation of organisms to their physical environment. Progress in Lipid Research, 29(3), 167227. https://doi.org/10.1016/0163-7827(90)90002-3

Hochachka, P. W., \& Somero, G. (2002). Biochemical adaptation: Mechanism and process in physiological evolution. Biochemistry and Molecular Biology Education, 30(3), 215-216. https://doi. org/10.1002/bmb.2002.494030030071

Hulbert, A. J., \& Else, P. L. (1999). Membranes as possible pacemakers of metabolism. Journal of Theoretical Biology, 199(3), 257-274. https:// doi.org/10.1006/jtbi.1999.0955

Hüning, A. K., Melzner, F., Thomsen, J., Gutowska, M. A., Krämer, L., Frickenhaus, S., Rosenstiel, P., Pörtner, H.-O., Philipp, E. E. R., \& Lucassen, M. (2013). Impacts of seawater acidification on mantle gene expression patterns of the Baltic Sea blue mussel: Implications for shell formation and energy metabolism. Marine Biology, 160(8), 1845-1861. https://doi.org/10.1007/s00227-012-1930-9

IPCC. (2019). IPCC special report on the ocean and cryosphere in a changing climate. (H. O. Pörtner, D. C. Roberts, V. Masson-Delmotte, P. Zhai, M. Tignor, E. Poloczanska, K. Mintenbeck, A. Alegría, M. Nicolai, A Okem, J. Petzold, B. Rama, \& N. M. Weyer, Eds.). https://www.ipcc. $\mathrm{ch} / \mathrm{srocc} / \mathrm{cite}-$ report/

IPCC. (2021). Climate change 2021: The physical science basis. Contribution of working group I to the sixth assessment report of the Intergovernmental Panel on Climate Change. (V. P. MassonDelmotte, A. Pirani, S.L. Connors, C. Péan, S. Berger, N. Caud, Y. Chen, L. Goldfarb, M.I. Gomis, M. Huang, K. Leitzell, E. Lonnoy, J.B.R. Matthews, T.K. Maycock, T. Waterfield, O. Yelekçi, R. Yu, \& B. Zhou, Eds.). Cambridge University Press. In Press.

Klopfenstein, D. V., Zhang, L., Pedersen, B. S., Ramírez, F., Warwick Vesztrocy, A., Naldi, A., Mungall, C. J., Yunes, J. M., Botvinnik, O., Weigel, M., Dampier, W., Dessimoz, C., Flick, P., \& Tang, H. (2018). GOATOOLS: A python library for gene ontology analyses. Scientific Reports, 8(1), 10872. https://doi.org/10.1038/s41598-018-28948-z

Knauer, J., \& Southgate, P. C. (1999). A review of the nutritional requirements of bivalves and the development of alternative and artificial diets for bivalve aquaculture. Reviews in Fisheries Science, 7(3-4), 241-280. https://doi.org/10.1080/10641269908951362
Ko, G. W. K., Dineshram, R., Campanati, C., Chan, V. B. S., Havenhand, J., \& Thiyagarajan, V. (2014). Interactive effects of ocean acidification, elevated temperature, and reduced salinity on early-life stages of the pacific oyster. Environmental Science \& Technology, 48(17), 10079-10088. https://doi.org/10.1021/es501611u

Kroeker, K. J., Kordas, R. L., Crim, R., Hendriks, I. E., Ramajo, L., Singh, G. S., Duarte, C. M., \& Gattuso, J.-P. (2013). Impacts of ocean acidification on marine organisms: Quantifying sensitivities and interaction with warming. Global Change Biology, 19(6), 1884-1896. https://doi. org/10.1111/gcb.12179

Langdon, C. J., \& Waldock, M. J. (1981). The effect of algal and artificial diets on the growth and fatty acid composition of Crassostrea gigas Spat. Journal of the Marine Biological Association of the United Kingdom, 61(2), 431-448. https://doi.org/10.1017/S002531540 0047056

Langfelder, P., \& Horvath, S. (2008). WGCNA: An R package for weighted correlation network analysis. BMC Bioinformatics, 9, 559. https:// doi.org/10.1186/1471-2105-9-559

Lannig, G., Eilers, S., Pörtner, H. O., Sokolova, I. M., \& Bock, C. (2010). Impact of ocean acidification on energy metabolism of oyster Crassostrea gigas-Changes in metabolic pathways and thermal response. Marine Drugs, 8(8), 2318-2339. https://doi.org/10.3390/ md8082318

Lee, H.-G., Stumpp, M., Yan, J.-J., Tseng, Y.-C., Heinzel, S., \& Hu, M.-Y.-A (2019). Tipping points of gastric $\mathrm{pH}$ regulation and energetics in the sea urchin larva exposed to $\mathrm{CO}_{2}$-induced seawater acidification. Comparative Biochemistry and Physiology Part A: Molecular \& Integrative Physiology, 234, 87-97. https://doi.org/10.1016/j. cbpa.2019.04.018

Lemasson, A. J., Hall-Spencer, J. M., Fletcher, S., Provstgaard-Morys, S., \& Knights, A. M. (2018). Indications of future performance of native and non-native adult oysters under acidification and warming. Marine Environmental Research, 142, 178-189. https://doi. org/10.1016/j.marenvres.2018.10.003

Leung, J. Y. S., Doubleday, Z. A., Nagelkerken, I., Chen, Y., Xie, Z., \& Connell, S. D. (2019). How calorie-rich food could help marine calcifiers in a $\mathrm{CO}_{2}$-rich future. Proceedings of the Royal Society $\mathrm{B}$ : Biological Sciences, 286(1906), 20190757. https://doi.org/10.1098/ rspb.2019.0757

Lutier, M., Di Poi Broussard, C., Gazeau, F., Appolis, A., Quere, C., Le Roy, V., Queau, I., Huber, M., Lugué, K., Le Luyer, J., \& Pernet, F. (2021). Transcriptomic, lipidomic, biometric and physiological rate data for the determination of the reaction norm of the Pacific oyster to ocean acidification. SEANOE. https://doi.org/10.17882/83294

Matz, M. V. (2018). Fantastic beasts and how to sequence them: Ecological genomics for obscure model organisms. Trends in Genetics, 34(2), 121-132. https://doi.org/10.1016/j.tig.2017.11.002

Meistertzheim, A.-L., Arnaud-Haond, S., Boudry, P., \& Thébault, M.-T. (2013). Genetic structure of wild European populations of the invasive Pacific oyster Crassostrea gigas due to aquaculture practices. Marine Biology, 160(2), 453-463. https://doi.org/10.1007/s00227-012-2102-7

Melzner, F., Thomsen, J., Koeve, W., Oschlies, A., Gutowska, M. A., Bange, H. W., Hansen, H. P., \& Körtzinger, A. (2013). Future ocean acidification will be amplified by hypoxia in coastal habitats. Marine Biology, 160(8), 1875-1888. https://doi.org/10.1007/ s00227-012-1954-1

Michaelidis, B., Ouzounis, C., Paleras, A., \& Pörtner, H. (2005). Effects of long-term moderate hypercapnia on acid-base balance and growth rate in marine mussels Mytilus galloprovincialis. Marine Ecology Progress Series, 293, 109-118. https://doi.org/10.3354/MEPS2 93109

Orr, J. C., Fabry, V. J., Aumont, O., Bopp, L., Doney, S. C., Feely, R. A., Gnanadesikan, A., Gruber, N., Ishida, A., Joos, F., Key, R. M., Lindsay, K., Maier-Reimer, E., Matear, R., Monfray, P., Mouchet, A., Najjar, R. G., Plattner, G.-K., Rodgers, K. B., ... Yool, A. (2005). Anthropogenic ocean acidification over the twenty-first century and its impact 
on calcifying organisms. Nature, 437(7059), 681-686. https://doi. org/10.1038/nature04095

Peck, V. L., Oakes, R. L., Harper, E. M., Manno, C., \& Tarling, G. A. (2018). Pteropods counter mechanical damage and dissolution through extensive shell repair. Nature Communications, 9(1), 264. https://doi. org/10.1038/s41467-017-02692-w

Peck, V. L., Tarling, G. A., Manno, C., Harper, E. M., \& Tynan, E. (2016). Outer organic layer and internal repair mechanism protects pteropod Limacina helicina from ocean acidification. Deep Sea Research Part II: Topical Studies in Oceanography, 127, 41-52. https://doi. org/10.1016/j.dsr2.2015.12.005

Peñaloza, C., Gutierrez, A. P., Eöry, L., Wang, S., Guo, X., Archibald, A. L., Bean, T. P., \& Houston, R. D. (2021). A chromosome-level genome assembly for the Pacific oyster Crassostrea gigas. GigaScience, 10(3). https://doi.org/10.1093/gigascience/giab020

Petton, B., Boudry, P., Alunno-Bruscia, M., \& Pernet, F. (2015). Factors influencing disease-induced mortality of Pacific oysters Crassostrea gigas. Aquaculture Environment Interactions, 6(3), 205-222. https:// doi.org/10.3354/aei00125

Proum, S., Harley, C. D., Steele, M., \& Marshall, D. J. (2017). Aerobic and behavioral flexibility allow estuarine gastropods to flourish in rapidly changing and extreme $\mathrm{pH}$ conditions. Marine Biology, 164(5), 97 https://doi.org/10.1007/s00227-017-3124-y

Rajan, K. C., Meng, Y., Yu, Z., Roberts, S. B., \& Vengatesen, T. (2021). Oyster biomineralization under ocean acidification: From genes to shell. Global Change Biology, 27(16), 3779-3797. https://doi. org/10.1111/gcb.15675

Rico-Villa, B., Pouvreau, S., \& Robert, R. (2009). Influence of food density and temperature on ingestion, growth and settlement of Pacific oyster larvae, Crassostrea gigas. Aquaculture, 287(3), 395-401. https://doi.org/10.1016/j.aquaculture.2008.10.054

Schneider, C. A., Rasband, W. S., \& Eliceiri, K. W. (2012). NIH image to ImageJ: 25 years of image analysis. Nature Methods, 9(7), 671-675. https://doi.org/10.1038/nmeth.2089

Smith, S. V., \& Key, G. S. (1975). Carbon dioxide and metabolism in marine environments. Limnology and Oceanography, 20(3), 493-495. https://doi.org/10.4319/lo.1975.20.3.0493

Sokolova, I. M. (2021). Bioenergetics in environmental adaptation and stress tolerance of aquatic ectotherms: Linking physiology and ecology in a multi-stressor landscape. Journal of Experimental Biology, 224(Suppl. 1). https://doi.org/10.1242/jeb.236802

Strader, M. E., Wong, J. M., \& Hofmann, G. E. (2020). Ocean acidification promotes broad transcriptomic responses in marine metazoans: A literature survey. Frontiers in Zoology, 17(1), 7-30. https://doi. org/10.1186/s12983-020-0350-9

Thomsen, J., Casties, I., Pansch, C., Körtzinger, A., \& Melzner, F. (2013). Food availability outweighs ocean acidification effects in juvenile Mytilus edulis: Laboratory and field experiments. Global Change Biology, 19(4), 1017-1027. https://doi.org/10.1111/gcb.12109

Timmins-Schiffman, E., Coffey, W. D., Hua, W., Nunn, B. L., Dickinson, G. H., \& Roberts, S. B. (2014). Shotgun proteomics reveals physiological response to ocean acidification in Crassostrea gigas. BMC Genomics, 15(1), 951. https://doi.org/10.1186/1471-2164-15-951

Tresguerres, M., Clifford, A. M., Harter, T. S., Roa, J. N., Thies, A. B., Yee, D. P., \& Brauner, C. J. (2020). Evolutionary links between intra- and extracellular acid-base regulation in fish and other aquatic animals. Journal of Experimental Zoology Part A: Ecological and Integrative Physiology, 333(6), 449-465. https://doi.org/10.1002/jez.2367

Tresguerres, M., \& Hamilton, T. J. (2017). Acid-base physiology, neurobiology and behaviour in relation to $\mathrm{CO}_{2}$-induced ocean acidification. Journal of Experimental Biology, 220(12), 2136-2148. https://doi. org/10.1242/jeb.144113

Vargas, C. A., Lagos, N. A., Lardies, M. A., Duarte, C., Manríquez, P. H., Aguilera, V. M., Broitman, B., Widdicombe, S., \& Dupont, S. (2017).
Species-specific responses to ocean acidification should account for local adaptation and adaptive plasticity. Nature Ecology \& Evolution, 1(4), 1-7. https://doi.org/10.1038/s41559-017-0084

Ventura, A., Schulz, S., \& Dupont, S. (2016). Maintained larval growth in mussel larvae exposed to acidified under-saturated seawater. Scientific Reports, 6(1), 23728. https://doi.org/10.1038/srep2 3728

Waldbusser, G. G., \& Salisbury, J. E. (2014). Ocean acidification in the coastal zone from an organism's perspective: multiple system parameters, frequency domains, and habitats. Annual Review of Marine Science, 6(1), 221-247. https://doi.org/10.1146/annurevmarine-121211-172238

Wallace, R. B., Baumann, H., Grear, J. S., Aller, R. C., \& Gobler, C. J. (2014). Coastal ocean acidification: The other eutrophication problem. Estuarine, Coastal and Shelf Science, 148, 1-13. https://doi. org/10.1016/j.ecss.2014.05.027

Wang, X., Wang, M., Jia, Z., Song, X., Wang, L., \& Song, L. (2017). A shellformation related carbonic anhydrase in Crassostrea gigas modulates intracellular calcium against $\mathrm{CO}_{2}$ exposure: Implication for impacts of ocean acidification on mollusk calcification. Aquatic Toxicology, 189, 216-228. https://doi.org/10.1016/j.aquatox.2017.06.009

Wang, X., Wang, M., Wang, W., Liu, Z., Xu, J., Jia, Z., Chen, H., Qiu, L., Lv, Z., Wang, L., \& Song, L. (2020). Transcriptional changes of Pacific oyster Crassostrea gigas reveal essential role of calcium signal pathway in response to $\mathrm{CO}_{2}$-driven acidification. The Science of the Total Environment, 741, 140177. https://doi.org/10.1016/j.scito tenv.2020.140177

Wood, S. N. (2001). Minimizing model fitting objectives that contain spurious local minima by bootstrap restarting. Biometrics, 57(1), 240244. https://doi.org/10.1111/j.0006-341X.2001.00240.x

Wright, J. M., Parker, L. M., O'Connor, W. A., Scanes, E., \& Ross, P. M. (2018). Ocean acidification affects both the predator and prey to alter interactions between the oyster Crassostrea gigas (Thunberg, 1793) and the whelk Tenguella marginalba (Blainville, 1832). Marine Biology, 165(3), 46. https://doi.org/10.1007/s0022 7-018-3302-6

Yan, L., Li, Y., Wang, Z., Su, J., Yu, R., Yan, X., Ma, P., \& Cui, Y. (2018). Stress response to low temperature: Transcriptomic characterization in Crassostrea sikamea $\times$ Crassostrea angulata hybrids. Aquaculture Research, 49(10), 3374-3385. https://doi.org/10.1111/are.13801

Yarra, T., Blaxter, M., \& Clark, M. S. (2021). A bivalve biomineralization toolbox. Molecular Biology and Evolution, 38(9), 4043-4055. https:// doi.org/10.1093/molbev/msab153

Zhao, X., Han, Y., Chen, B., Xia, B., Qu, K., \& Liu, G. (2020). CO $\mathrm{CO}_{2}$-driven ocean acidification weakens mussel shell defense capacity and induces global molecular compensatory responses. Chemosphere, 243, 125415. https://doi.org/10.1016/j.chemosphere.2019.125415

\section{SUPPORTING INFORMATION}

Additional supporting information may be found in the online version of the article at the publisher's website.

How to cite this article: Lutier, M., Di Poi, C., Gazeau, F., Appolis, A., Le Luyer, J., \& Pernet, F. (2022). Revisiting tolerance to ocean acidification: Insights from a new framework combining physiological and molecular tipping points of Pacific oyster. Global Change Biology, 28, 33333348. https://doi.org/10.1111/gcb.16101 